\title{
CHINA, CULTURAL HERITAGE, AND INTERNATIONAL LAW
}

Hui Zhong 


\section{China, Cultural Heritage, and International Law}

China is a country that is rich in antiquities, but it is also a victim of looting that occurred during the period from the First Opium War to the end of the Japanese Occupation (1840-1945) when innumerable cultural objects were lost overseas. The Chinese Government insists on asserting its interest over its wrongfully removed cultural heritage and has sought for the return of lost cultural heritage by all means in accordance with relevant international conventions and Chinese laws. However, securing the return has been, and continues to be, problematic. Little research has been done regarding the question as to whether China has a legal basis for recovery, which is the first legal hurdle that China needs to get over. In addition, China does not have a legal basis for all cultural heritage taken during the period of 1840-1945. Claims for return without a legal basis are usually silenced or, at best, discussed only but very rarely facilitated.

This book provides an answer for the return of Chinese cultural heritage. It examines the law contemporaneous to the removal of Chinese cultural heritage and its application. For this lack of a legal basis, this book argues that a new customary international law is emerging, according to which the interests of the states of origin in their wrongfully removed heritage should be prioritised. This proposed customary rule supports the return of wrongfully removed heritage. Once this proposed customary rule is accepted, it will provide a stronger argument not only for China, but also for other states of origin with a similar dilemma, including South Korea, Egypt, Greece, Cambodia, Turkey, Peru, and Italy, to recover their wrongfully removed heritage.

While dealing with a large pool of return cases, this book is valuable to museums and art collectors in the event of buying and accepting art objects, and settling recovery disputes with states of origin. It will also be of interest to researchers, academics, policymakers, and students in the fields of cultural heritage law, international law, international trade, and human rights law.

Hui Zhong is a research fellow at South China Sea, Xiamen University, China. 


\section{Routledge Research in International Law}

For a full list of titles in this series, visit www.routledge.com/RoutledgeResearch-in-International-Law/book-series/INTNLLAW

Available:

Peacemaking, Religious Belief and the Rule of Law

The Struggle between Dictatorship and Democracy in Syria and Beyond Paul Zwier

China, Cultural Heritage, and International Law Hui Zhong

The UN Security Council and Domestic Actors

Distance in International Law

Machiko Kanetake

Human Security Discourse and International Law

A Principled Approach

Shireen Daft

Fighting and Victimhood in International Criminal Law Joanna Nicholson

Prosecuting Juvenile Piracy Suspects

The International Legal Framework

Milena Sterio

Nationalization, Natural Resources and International Investment Law Contractual Relationship as a Dynamic Bargaining Process

Junji Nakagawa

Queering International Law

Possibilities, Alliances, Complicities, Risks

Edited by Dianne Otto

Sovereignty Conflicts and International Law and Politics

A Distributive Justice Issue

Jorge E. Núñez 


\section{China, Cultural Heritage, and International Law}

\section{Hui Zhong}


First published 2018

by Routledge

711 Third Avenue, New York, NY 10017

and by Routledge

2 Park Square, Milton Park, Abingdon, Oxon OX14 4RN

Routledge is an imprint of the Taylor \& Francis Group, an informa business

\section{(C) 2018 Hui Zhong}

The right of Hui Zhong to be identified as author of this work has been asserted by her in accordance with sections 77 and 78 of the Copyright, Designs and Patents Act 1988.

All rights reserved. No part of this book may be reprinted or reproduced or utilised in any form or by any electronic, mechanical, or other means, now known or hereafter invented, including photocopying and recording, or in any information storage or retrieval system, without permission in writing from the publishers.

Trademark notice: Product or corporate names may be trademarks or registered trademarks, and are used only for identification and explanation without intent to infringe.

Library of Congress Cataloging-in-Publication Data

Names: Zhong, Hui (Writer on law) author.

Title: China, cultural heritage, and international law / Hui Zhong. Description: Abingdon, Oxon [UK] ; New York : Routledge, 2018. | Series: Routledge research in international law | Includes index.

Identifiers: LCCN 2017036625 | ISBN 9781138093249 (hardback) | ISBN 9781351605700 (web pdf) | ISBN 9781351605694 (epub) | ISBN 9781351605687 (mobipocket)

Subjects: LCSH: Cultural property-Protection-Law and legislation-China-History. | Cultural property-Protection (International law) | Customary law, International.

Classification: LCC KNQ3183.Z465 2018 | DDC $344.51 / 094-\mathrm{dc} 23$

LC record available at https://lccn.loc.gov/2017036625

ISBN: 978-1-138-09324-9 (hbk)

ISBN: 978-1-315-10696-0 (ebk)

Typeset in Galliard

by Apex CoVantage, LLC 


\section{Contents}

Table of Cases

Table of Legislation, Conventions and Treaties

vi

Preface and Acknowledgements

1 Introduction

2 States of Origin and Cultural Heritage

3 Availability of a Legal Basis for the Return of China's Cultural Heritage

4 Customary International Law

5 Return of Cultural Heritage Looted during Armed Conflicts

6 Return of Cultural Heritage Stolen and Illegally Exported in Peacetime

7 Evolving Social and Ethical Norms: Practice of Individuals, Private Museums, and Auction Houses

8 Return of Historically Removed Heritage 


\section{Table of Cases}

Asylum Case (Colombia v Peru) 1950 ICJ Rep 266 ......................................74, 76

Attorney General of New Zealand v Ortiz [1982] 3 All ER 432 ...................51, 141, 147

Bakalar v Vavra 819 F.Supp.2d 293, 307 (SDNY 2011) .......................................... 153

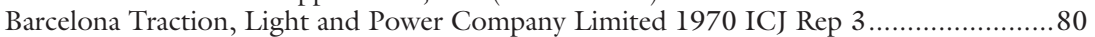

Continental Shelf Case (Libya v Malta) 1985 ICJ Rep 13 ......................................73, 75

Delimitation of the Maritime Boundary in the Gulf of Maine Area (Canada v

United States of America), Judgment, October 12 1984, 1984 ICJ Rep 305 ...........81

Deweerth v Baldinger 38 F.3d 1266 (2d Cir.) cert. denied 513 U.S. 1001 (1994) ........157

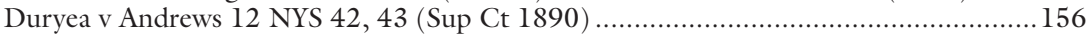

Fisheries Case (UK v Norway) 1951 ICJ Rep 116...............................74, 80, 82, 83

Government of Peru v Johnson (720 F Supp 810, CD Cal 1989) ... 51, 113, 114, 128, 129

Government of the Islamic Republic of Iran v The Barakat Galleries Ltd [2007]

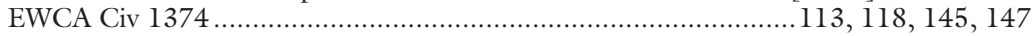

Menzel v List 267 NYS2d 804, 809 (Sup Ct NY 1966), reversed, 246 NE 2d

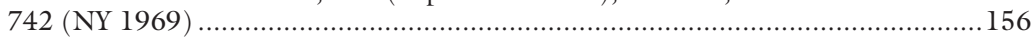

North Sea Continental Shelf Cases, 1969 ICJ Rep 43 ..............................73, 74, 78, 79, 81

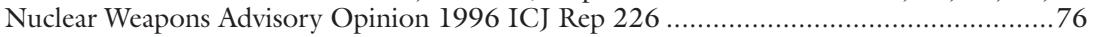

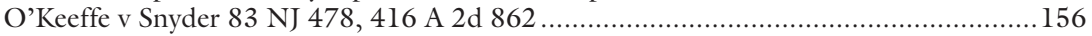

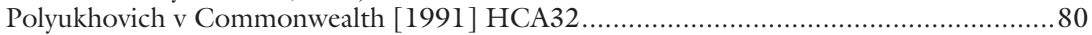

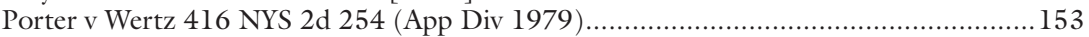

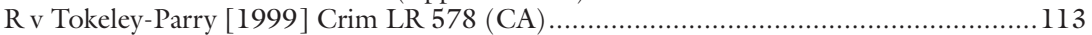

Republic of Turkey v Metropolitan Museum of Art 762 F Supp 44 (SDNY 1990). 115, 132

Republic of Turkey v OKS Partners 1994 US Dist LEXIS 17032 (D Mass 1994).....

$113,130,132$

Republic of Turkey v The Metropolitan Museum of Art 762 F Supp 44, 1990 US Dist LEXIS 18771 (SDNY 1990) _.................................................129, 156

SS "Lotus" Case 1927 PCIJ 28 ……...........................................................

United States of America v A 10th Century Cambodian Sandstone Sculpture, Currently Located at Sotheby's in New York, New York No. 12-cv2600-GBD (SDNY March 28 2013)

United States v Mask of Ka-Nefer-Nefer No. 12-2578 (8th Cir June 12 2014), affirming 11-CV-504-HEA (ED Mo March 31 2012) ...............................173, 174

United States v McClain (545 F 2d 988, 5th Cir, reh'g denied, 551 F 2d 52, 5th Cir 1977).

United States v Schultz 178 F Supp 2d 445 (SDNY 2002), aff'd, 333 F 3d 393 (2d Cir 2003) $126,127,132,146$

Winkworth v Christie Manson \& Woods Ltd [1980] Ch 496, [1980] 1 All ER 1121 150 


\section{Table of Legislation, Conventions and Treaties}

\section{Legislation}

Act implementing the Convention of May 141954 for the Protection of Cultural Property in the Event of Armed Conflict 2007 (Germany)

s. 1

Act on the Return of Cultural Property 2007 (Germany) …...............................140, 143

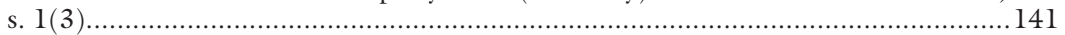

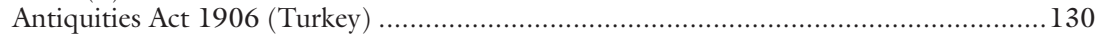

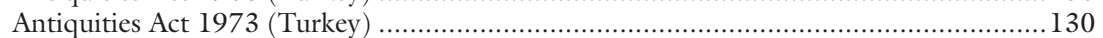

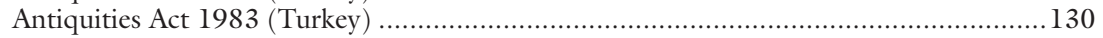

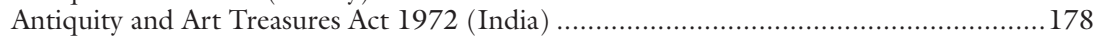

Archaeological Resources Protection Act (ARPA) (USA) ............................................ 125

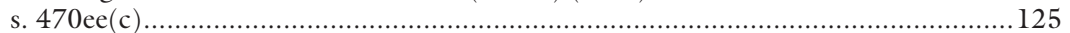

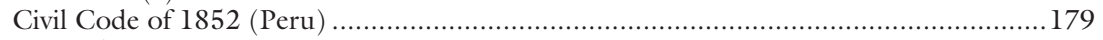

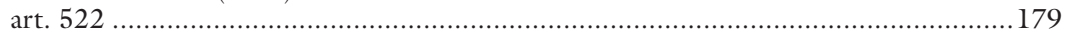

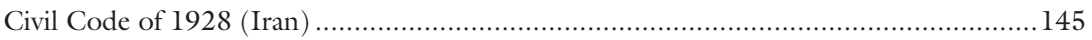

Council Directive 93/7/EEC of March 151993 on the return of cultural objects unlawfully removed from the territory of a Member State.....................122, 123

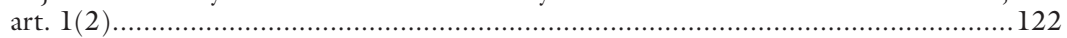

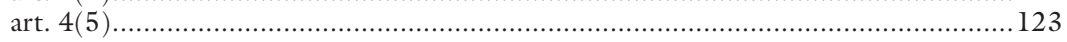

art. 2 .

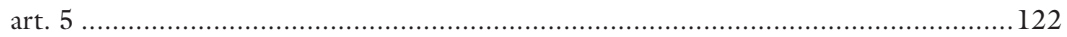

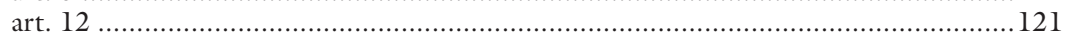

Council Directive 2014/60/EU of the European Parliament and of the

Council of May 152014 on the return of cultural objects unlawfully

removed from the territory of a Member State and amending

Regulation (EU) No 1024/2012 (Recast) ..........................................123, 149, 152

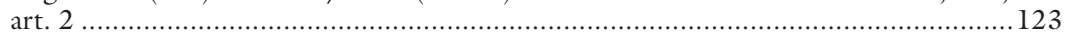

art. 5

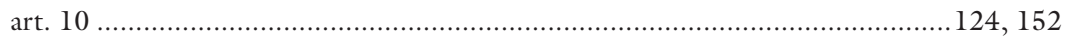

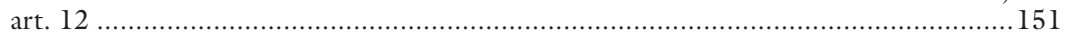

Council Regulation No. 3911/1992 on the export of cultural goods .........................122

Council Regulation (EU) No 1332/2013 of 13 December 2013 Amending

Regulation (EU) No 36/2012 Concerning Restrictive Measures in View of the Situation in Syria

art. 11c.

Cultural Property Originating from Occupied Territory Return Act 2007

(Netherlands) …........................................................................... 101, 102

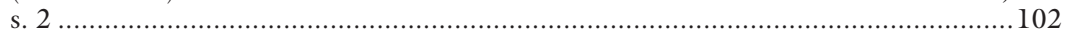

ch. 2 .

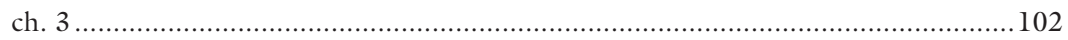

Cultural Property Implementation Act (CPIA) (USA).................125, 126, 127, 131, 133

Customs and Excise Management Act 1979 (CEMA) (UK) ........................................ 146

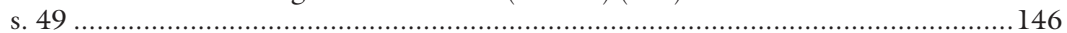


Dealing in Cultural Objects (Offences) Act 2003 (UK)......... 121, 143, 144, 146, 147, 148

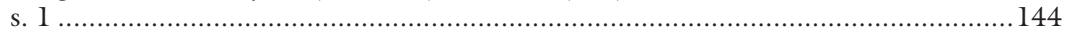

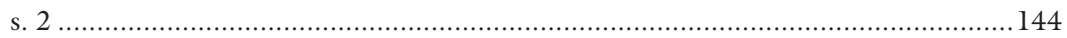

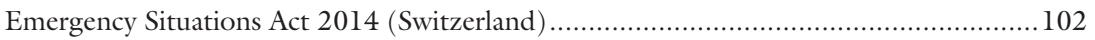

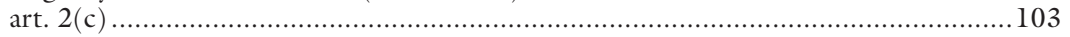

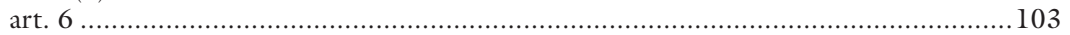

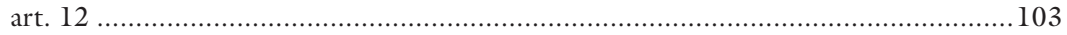

(1)

Export Control (Syria Sanctions) (Amendment) Order 2014 (SI 2014

No. 1896) (UK)

Federal Act on the International Transfer of Cultural Property (CPTA)

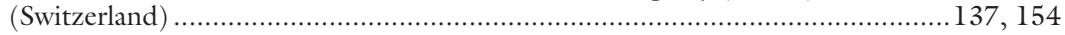

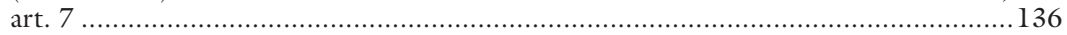

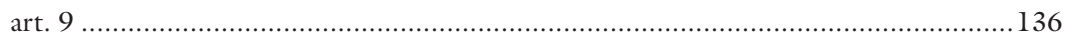

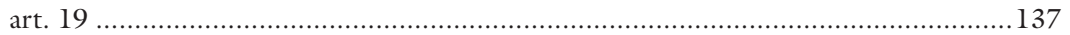

(2)

art. 24(1)-(3)

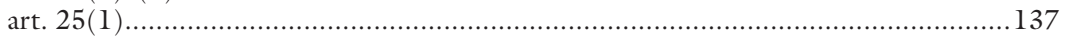

Federal Law on the Protection of Cultural Objects in the Event of Armed Conflict, Disaster and

German Civil Code s. 138

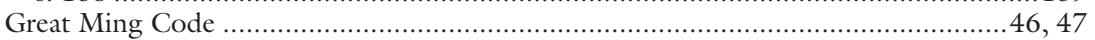

Article 36 - Committing Crimes by Persons beyond the Pale of Civilization of

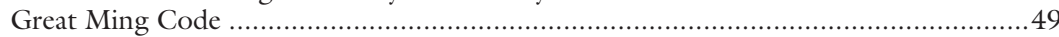

Article 280 - Stealing Sacred Objects of the Spirits Devoted to the Great Sacrifices

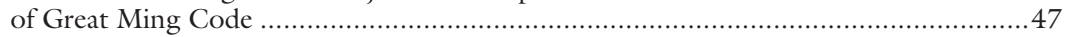

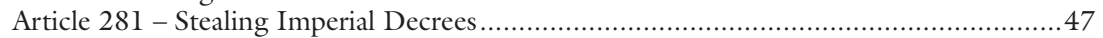

Article 283 - Stealing Property from the Palace Treasury …….................................... 47

Article 286 - Stealing Plants or Trees within the Imperial Mausoleum ...........................47 Great Qing Code ….......................................46, 47, 48, 49, 50, 51, 52, 53, 63, 64

Section XXXIV - Offences committed by Foreigners of Qing Code...............................49

Section CLXXXIII - Unauthorized entering the Imperial Temple ….............................48

Section CLXXXIV - Unauthorized entering the Imperial Palace....................................48

Section CXCII - Shooting or throwing missile weapons towards an Imperial Palace .........48

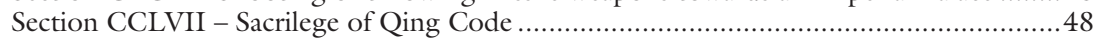

Section CCLX - Stealing from an Imperial Palace ................................................... 48

Section CCLXV - Theft of Public Property .............................................................. 48

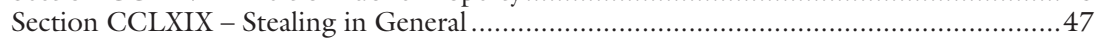

Section CCCLXXVI - Defacing or Destroying Public Monuments...................................... 48

Iraq (United Nations Sanctions) Order 2003 (SI 2003 No. 1519) (UK) .......................... 105

Law of the People's Republic of China on Protection of Cultural Relics 2002

art. 2

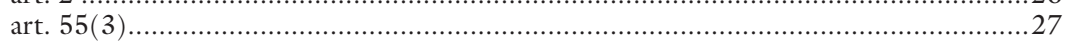

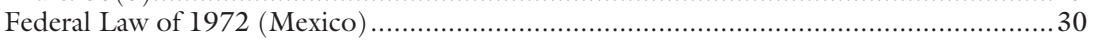

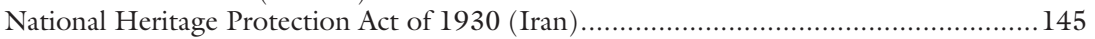

National Stolen Property Act (NSPA) (USA) ……......................................125, 127

Private International Law (Belgium)

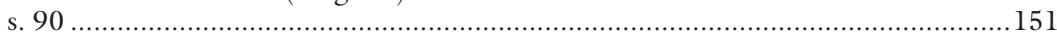

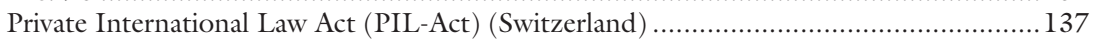

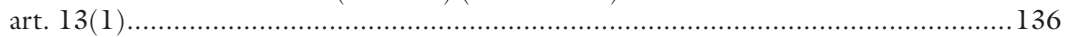

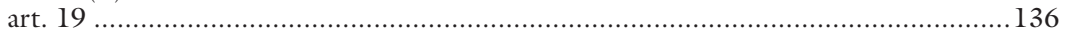

Protection of Moveable Cultural Act of 1986 (Australia) ......................................... 178

Regulation of Importation of Pre-Columbian Monumental or Architectural Sculpture or Mural (USA).....

Statute of the International Court of Justice (ICJ) art. 38(1)...

Supreme Decree of 1893 (Peru) art. 1 


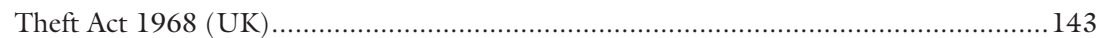

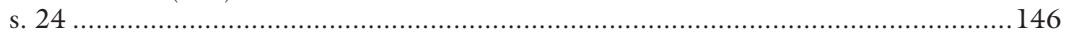

Turkish Civil Code

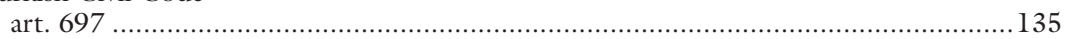

United States Cultural Property Implementation Act (CIPA) (USA) …............................22

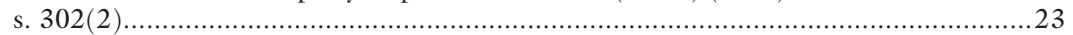

United States Importation of Pre-Columbian Monumental or Architectural Sculpture or

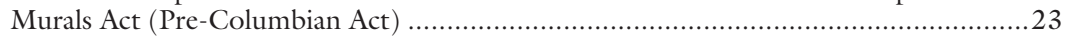

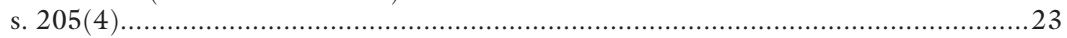

\section{Conventions}

Hague Convention on the Laws and Customs of War on Land

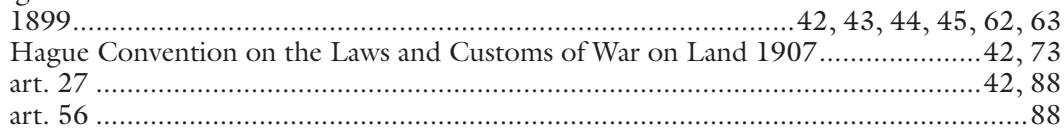

Convention on the Means of Prohibiting and Preventing the Illicit Import,

Export and Transfer of Ownership of Cultural Property (1970 UNESCO

Convention) ................................................................... $6,22,96,116,117$, $118,119,125,128,131,132,136,137,140,142,143,147,148,149,154,157,166$, $168,178,187,191,196,197$

Preamble

art. 1

116

art. $2(1)$

112

(2)

.96

art. 3

116

(2)

art. 5 .

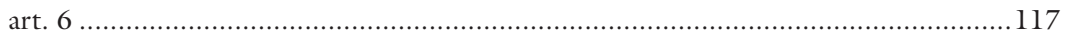

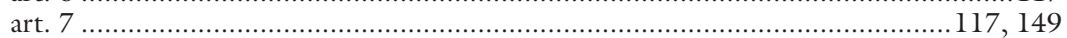

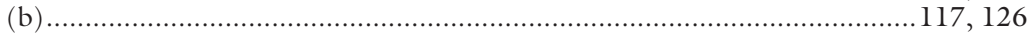

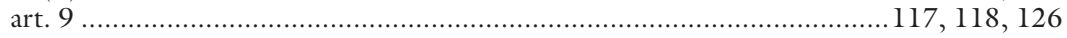

(1)

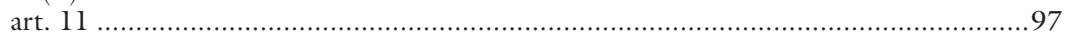

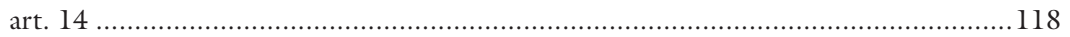

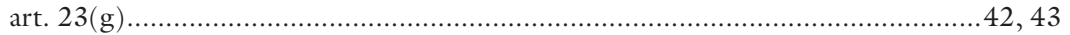

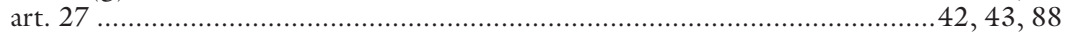

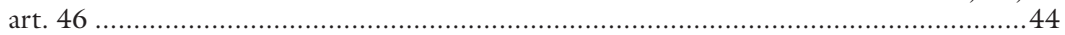

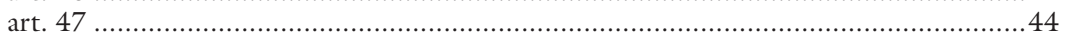

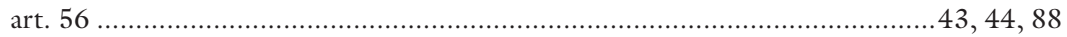

Convention for the Protection of Cultural Property in the Event of Armed Conflict

(1954 Hague Convention) .................................................... 6, 99, 100, 101, 191

Convention on the Settlement of Matters Arising out of the War and the Occupation 1952

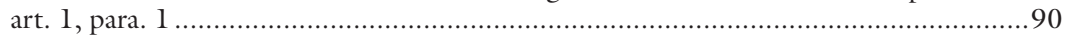

Convention on Stolen or Illegally Exported Cultural Object

(1995 UNIDROIT Convention) ..........6, 119, 120, 121, 147, 151, 152, 155, 168, 196

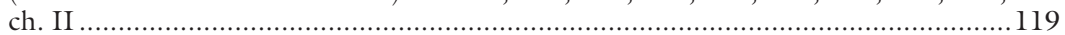

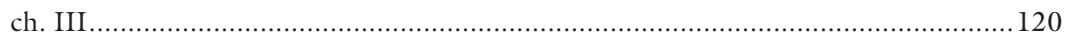

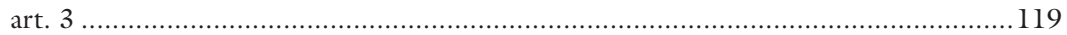

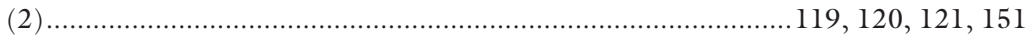

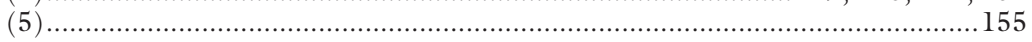

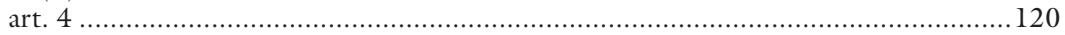

(4)

art. 5(1) (3) 120

(3)

(5)

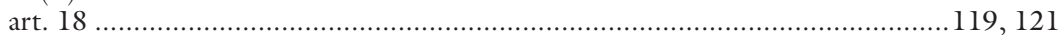




\section{$\mathrm{x}$ Table of Legislation, Conventions and Treaties}

Protocol for the Protection of Cultural Property in the Event of Armed Conflict (First Protocol-May 14 1954, 249 UNTS 358)

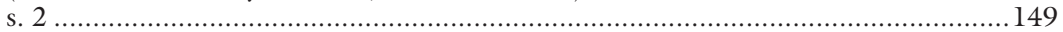

s. 3 .

s. 6 .

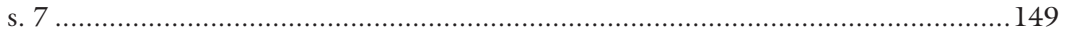

Second Protocol to the Hague Convention for the Protection of Cultural Property in the Event of Armed Conflict (Second Protocol-March 26 1999,

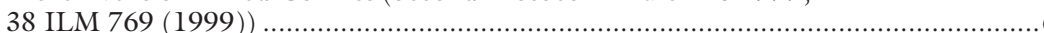

\section{Treaties}

Treaty on the Functioning of the European Union (TFEU)

art. 36

Treaty of Peace between the Allied and Associated Powers and Italy 1947 art. 37

Treaty on the Protection of Movable Property of Historic Value 1936

(Treaty of Washington)

art. 1

art. 2

art. 3

art. 6

Treaty of Versailles 1919

art. 245 


\section{Preface and Acknowledgements}

I always felt very proud when I saw Chinese art treasures exhibited in foreign museums, until Christie's announced that the two bronzes, a rat head and a rabbit head would be auctioned in Paris in February 2009. These two bronze statues were taken from Beijing's Summer Palace by Anglo-French troops during the First Opium War (1856-1860). After Christie's announcement, the Chinese Government resolutely urged Christie's to stop the sale, stating that the auction would "seriously hurt national sentiment". For many Chinese, the looting of the Summer Palace has become a source of bitterness, as China's highest culture had been ignored and violently destroyed by Anglo-French troops. A group of Chinese lawyers tried to block the auction, but a French court allowed it to proceed. The two bronze statues were still auctioned for sale, but the auction ended in controversy. This auction made me start thinking about the reasons that make recovery difficult, as well as the possibility for recovery.

To answer these questions, I began my research at the University of Queensland, Australia. Until then, I had not realised the difficulties involved in returning these treasures to the place where they were originally created. China is a country that is rich in antiquities, but it is also a victim of looting that occurred during the period from the First Opium War to the end of the Japanese Occupation (1840-1945). Innumerable cultural objects were lost overseas. However, there are relatively few studies relating to the looting and destruction that occurred between 1840 and 1945. While the Nazi's looting of before and during the Second World War has been condemned, Japan's systematic plunder and destruction of China's cultural heritage during the same war is seldom discussed. The damage to Chinese cultural heritage tends to be forgotten. Furthermore, instead of pressing formal demands for repatriation, the approach used to bring scattered Chinese arts home is still limited to donation, buying-back and diplomatic negotiation. One of the reasons for this is that there is no clear answer as to whether China has a legal basis for the recovery. Little research has been done regarding the law in the Qing Dynasty (1644-1911) and law in the Republic of China (1911-1949), and its application to the removal of China's cultural heritage.

As the research progressed, I also realised that China is not the only country that has been active in pursuing the return of its cultural heritage. In the past 
few decades, other states of origin have been expecting the return of their cultural heritage: Greece has been requesting the return of the Parthenon Marbles for decades; South Korea has been requesting the return of its Ugiew, the historical books about its Joseon Dynasty (1392-1910); Egypt has been seeking the return of the Rosetta Stone and Nefertiti; and Nigeria has been demanding the return of the Benin bronzes. However, securing the return has been, and continues to be, problematic. As removals often occurred a long time prior, many claims are time barred, additionally many records and other evidence may have disappeared, and international conventions are not retroactive. Most importantly, there is no law contemporaneous to the removal determining such taking as illegal. Even though the taking was morally wrong, it was perfectly legal. Claims for the return without a legal basis are usually silenced or, at best, discussed only but very rarely facilitated.

For this lack of a legal basis, this book aims to provide an answer. This book argues that a new customary international law is emerging, according to which the interests of the states of origin in their wrongfully removed heritage should be prioritised. This proposed customary rule supports the return of historically removed heritage, including Chinese cultural heritage that was lost overseas between 1840 and 1945. During the past two decades, more and more cultural heritage objects have been returned to the states of origin by individuals, museums and states. Both international and national laws have evolved in the direction of favouring and respecting the interests of the states of origin in their cultural heritage. One of the consequences is that museums have adopted stricter policies when buying and accepting art objects. These facts support the idea of a new, emerging customary rule. Once this proposed customary rule is accepted as a new customary rule, it will provide a stronger argument not only for China, but also for other states of origin with a similar dilemma, including South Korea, Egypt, Greece, Cambodia, Turkey, Peru, and Italy, to recover their wrongfully removed heritage.

This book is based on my thesis submitted and defended at the University of Queensland for the degree of Doctor in Philosophy. And this brings me to many thanks. The most sincere thanks are due to Professor Craig Forrest, who supervised my doctoral thesis. I really appreciate the way he guided me to undertake academic research and gave me this opportunity to have my questions answered. He provided me with illuminating guidance, precious advice and constant encouragement through the years of my study. I am incredibly fortunate to have had such a good supervisor. I also owe a debt of gratitude to Professor Janet Ulph who offered precious comments and support during my visiting study at the University of Leicester. Thanks also to Dr Justine Bell, who commented on my work and allowed me to improve my thesis.

I also wish to thank Professor Elina Moustaira and Dr Christa Roodt for their valuable advice and comments on all aspects of my thesis. Thanks also to the anonymous reviewers. Their feedback was nothing less than extraordinary.

I am so grateful to my colleagues in the South China Sea Institute, Xiamen University. Special thanks to Professor Kuen-chen FU for offering the 
opportunity to continue my research in underwater cultural heritage and law of the sea.

I would also like to express my gratitude to China Scholarship Council for funding my study in Australia. I am fortune with the opportunity of doing my $\mathrm{PhD}$ in the TC Beirne School of Law.

A special thank you goes to my parents, for their unfailing encouragement, for their continuous belief in me and for their unreserved love. 
$\because$ Taylor \& Francis

Taylor \& Francis Group

http://taylorandfrancis.com 


\section{Introduction}

\section{Introduction}

On April 26 2013, the French Pinault family announced that they would donate two $\$ 40$ million bronze statues to China. ${ }^{1}$ The two bronzes, a rat head and a rabbit head, were among 12 animal heads, replicating the Chinese zodiac, in a central fountain clock at Beijing's Summer Palace, also known as Yuanmingyuan and used by rulers of the Qing dynasty, spewing water to tell time. All disappeared after the Palace was destroyed by Anglo-French troops during the Second Opium War (1856-1860). The return of the two bronze statues enjoyed a warm welcome in China, with the State Administration of Cultural Heritage in China stating that Mr. Pinault's offer was “an expression of friendship toward the Chinese people". At the same time, however, it also reminded the Chinese people of the auction of the same two bronze sculptures four years earlier.

In 2009, when the statues were put up for auction in Paris, China attempted to stop the sale. The Chinese State Administration of Cultural Heritage $(\mathrm{SACH})$ resolutely urged Christie's to stop the sale, stating that the auction would "seriously hurt national sentiment". ${ }^{2}$ To China, the looting of the palace epitomises the humiliation it suffered at the hands of imperial Western powers during the Second Opium War. However, Christie's refused to pull the bronze statues from the auction, as it continued to believe that "sale by public auction offers the best opportunity for items to be repatriated as a result of worldwide exposure". ${ }^{3}$ A group of Chinese lawyers also launched a legal bid in a Paris court to stop the sale. However, the court ruled against stopping the auction, concluding that the plaintiff did not have a direct interest in the two statues and therefore no standing before the court. The auction ended in

1 Edward Wong and Steven Erlanger, 'Frenchman Will Return to China Prized Bronze Artifacts Looted in 19th Century', The New York Times April 262013 <www.nytimes. $\mathrm{com} / 2013 / 04 / 27 /$ world/europe/frenchman-will-return-to-china-prized-bronze-arti facts-looted-in-19th-century.html>.

2 'China Condemns Christie's Auction', The BBC News February $262009<$ http://news. bbc.co.uk/2/hi/asia-pacific/7911691.stm>.

3 Ibid. 


\section{Introduction}

controversy. After China failed to block the sale legally, a Chinese businessman successfully bid for them, but refused to pay as a "patriotic" act. Convinced that he had fulfilled his duty as a Chinese citizen, he further stated that "these cultural relics belong to China . . . they were looted by the West in time of war and illegally taken abroad". ${ }^{4}$ After the auction sale, the SACH announced new limits against Christie's. ${ }^{5}$ Specifically, the Chinese Government tightened the ownership control over all cultural relics that Christie's seeks to import or export.

This auction case clearly reflects the importance that societies attach to their cultural relics, which is why related discussions can easily become emotional. ${ }^{6}$ Cultural relics are often the symbols for times of victory, defeat, great suffering, or important occasions in the history of a society. ${ }^{7}$ However, a large number of such cultural relics were taken out of China during times of war and peace, and particularly during the period beginning with the First Opium War to the end of Japanese Occupation (18401949). China has since been expecting the return of its scattered cultural relics. ${ }^{8}$ During David Cameron's 2013 visit in China, he was inundated with demands for the restitution of cultural objects taken from the country. ${ }^{9}$ When the British officials set up the official page on the Chinese social network "Sina Weibo", China's version of Twitter, one of the most popular questions concerned the return of Chinese cultural relics. However, securing the return of the relics taken during this period has been and continues to be problematic.

4 Yu Zhang, 'France Returning Treasure to China Sets Precedent for Further Restitutions', Global Times September 92015 <www.globaltimes.cn/content/941506.shtml>.

5 'China Tightens Control on Christie's After Auction', The Xinhua News February 26 2009 <http://news.xinhuanet.com/english/2009-02/26/content_10901300.htm>.

6 Scholarship in this area now clearly differentiates these terms, such as cultural heritage, cultural property, return, repatriation and restitution. For more discussion, see Lyndel Prott and Patrick O'Keefe, “"Cultural Heritage" or "Cultural Property"?' (1992) 1(2) International Journal of Cultural Property 307; Wojciech Kowalski, 'Types of Claims for Recovery of Lost Cultural Property' (2005) 57(228) Museum International 85.

But in Chinese legal documents, the terms antiquities, ancient objects, and cultural relics, are more commonly used. This book will use cultural heritage and return in most of its context as the primary purpose of this book is arguing for a new customary rule based on the increasing recognition of connection between states of origin and cultural heritage. But when analysing Chinese legislation, this book will use the relevant terms according to the context in which they appear.

7 Stefan Gruber, 'The Fight Against the Illicit Trade in Asian Cultural Artefacts: Connecting International Agreements, Regional Co-operation, and Domestic strategies' (2013) 3(2) Asian Journal of International Law 341, 343.

8 China's recovery efforts will be discussed in Chapter 2.

9 " "Give Us Back Our Treasure": Chinese Demand Cameron Returns Priceless Artefacts Looted during 19th Century Boxer Rebellion', Mail Online December 42013 <www. dailymail.co.uk/news/article-2518111/China-demand-David-Cameron-return-BoxerRebellion-artefacts.html>. 


\section{A Victim of Loss of Cultural Heritage}

China has an abundance of cultural relics created through its history of more than 5,000 years. However, due to the decay of the Qing Government and the military superiority of European forces, China was forced to open its gates after the defeat in the First Opium War in 1840, and incurred invasions from foreign countries. ${ }^{10}$ During this period, China was dragged into the First Opium War (1840-1842), the Second Opium War (1857-1860), the Sino-French War (1883-1885), the First Sino-Japanese War (1894-1895), the Pillage of Beijing by Eight-Nation Alliance (1900), ${ }^{11}$ the British invasion of Tibet (1903-1904), the First World War (1917-1918) and the Second World War (also known as the Japanese Occupation, 1937-1945). ${ }^{12}$ China lost almost all of the wars it fought, and was forced to give major concessions to the great powers in the subsequent treaties. At the same time, China was plagued by destruction and a large-scale loss of its cultural heritage on a large scale. ${ }^{13}$ Generally speaking, Chinese cultural heritage was lost in two ways: first, plunder and looting in times of armed conflicts; and, second, taking by individual behaviours, such as expedition, theft and exportation, during both times of war and peace.

Large-scale looting during wartimes have resulted in massive losses of Chinese cultural heritage, in particular, during the sacking of the Summer Place by Anglo-French troops during the Second Opium War (1856-1860), the plunder of Beijing by the Eight-Nation Alliance in the Battle of Beijing (1900); and the Japanese looting in the Second Sino-Japanese War (19311935). For example, the Old Summer Palace was where the emperors of the Qing Dynasty lived and handled government affairs. Reputed as the "Garden of Gardens", the Summer Palace is well-known for its magnificent architecture and extraordinary history, as it took the Qing people from 1709 to 1772 to complete this grand complex of buildings and gardens. Also, countless priceless Chinese artworks, antiquities, unique copies of literary works and compilations were collected from all over the country and stored in this Palace. However, when Anglo-French forces occupied Beijing, the invaders torched

10 For more historical backgrounds, see John King Fairbank, The Cambridge History of China Volume 10: Late Ch'ing 1800-1911, Part 1 (Cambridge University Press, 1978); David Scott, China and the International System, 1840-1949: Power, Presence, and Perceptions in A Century of Humiliation (State University of New York Press, 2008).

11 The Eight-Nation Alliance was an international coalition set up in response to the Boxer Rebellion by the nations of Japan, Russia, the British Empire, France, the US, Germany, Italy, and Austria-Hungary.

12 Japan started fighting against China intermittently since 1931, but the total war started in 1937.

13 This book will not go to the details of the loss of Chinese cultural heritage. For more details, see Lei Peng, A Research on Legal History of Return of Relics (in Chinese) (Nanjing: Yilin Publishing, 2012); Zuozhen Liu, The Case for Repatriating China's Cultural Objects (Springer, 2016), Chapter 1. 


\section{Introduction}

or levelled as many as 200 buildings, stripping a nearly thousand-acre site of sculptures, silk robes and jewellery. ${ }^{14}$

Japan is another major destination for the looted Chinese cultural heritage. During the Second Sino-Japanese War, public museums, libraries, imperial palaces and private houses were all targets of pillage for Japanese troops due to Japan's notorious “Three Alls Campaign”, also known as "Burn all, loot all, and kill all". ${ }^{15}$ The damage to China's cultural heritage during the armed conflicts was massive. ${ }^{16}$ For example, Chongqing, with a long history dating back at least 3,000 years, enjoys a prestigious historical reputation and is famous for a series of Chinese religious sculptures and carvings, depicting and influenced by Buddhist, Confucian and Taoist beliefs. However, the 1939 carpet bombing of Chongqing in two days of air raids was described by a survivor as "a sea of fire". It was reported that 741 historical sites, more than 15,000 paintings and over 3,000,000 books were damaged or destroyed in this act. ${ }^{17}$ It was also reported that only in 1944, 11,022 volumes of ancient books in the Forbidden City and 1,372 pieces of treasures in the Peking History Museum were pillaged by the Japanese. ${ }^{18}$

Apart from war looting, countless Chinese cultural heritage was stolen, excavated, and exported from China by individuals during both times of war and peace. Since the end of the 19th century, foreign explorers, sinologists and missionaries had come to China to collect Chinese cultural heritage. During the period of 1850 and 1940, 151 archaeological explorations were conducted by foreign expedition teams in Northwest China. ${ }^{19}$ The most wellknown example occurred in 1907 when Auriel Stein convinced the guardian in the Mogao Grottoes to sell a collection of 260 paintings and more than 8,000 manuscripts to the British Museum. ${ }^{20}$

In a recent donation case in 2014, seven marble columns from the Summer Palace were handed over to China from the KODE Art Museums of Bergen, a

14 Karl Meyer, 'The Chinese Want Their Art Back', New York Times June 202015 <www. nytimes.com/2015/06/21/opinion/the-chinese-want-their-art-back.html?_r=0>.

15 Louis G. Perez, Japan at War: An Encyclopedia (ABC-CLIO, 2013), 484.

16 For a general account of the Japanese plunder, see Yan Changhong and Li Xia, 'A Review of Japan's Cultural Aggression against China during Anti-Japanese War' (in Chinese)' (2005) 25(4) Journal of South-Central University for Nationalities (Humanities and Social Sciences) 12.

17 'War Damage on Cultural Relics Commission under the Department of Education', China Cultural Relics August 22, 2007 <www.xhgxt.com/html/View_9270.html>.

18 Peng, A Research on Legal History, above n 13, 26-34.

19 Twenty explorations were conducted by Germans, 53 by Russians, 30 by British, one by Hungarian, 13 by Japanese, eight by French, three by American, 22 by Swedish, and one by an unknown expedition team. Ibid, 34-55; Liu, Repatriating China's Cultural Objects, above n 13, 13.

20 James Cuno, Who Owns Antiquity?: Museums and the Battle over Our Ancient Heritage (Princeton University Press, 2008), 88-89. 
Norwegian museum. ${ }^{21}$ The columns were part of an over 4,000-piece collection of Chinese artefacts in the KODE museum that were donated by Johan Munthe between 1907 and 1935. Munthe lived in China from 1886 to 1935 and was first employed in the Chinese customs service. He fought on the Chinese side in the First Sino-Japanese War and was named a lieutenant general by Yuan Shikai, who would later become the first president of the Republic of China. As an avid collector of Chinese art, Munthe had a significant collection of Chinese sculpture, jade, porcelain, paintings and Chinese antiques. However, it was unclear how he obtained and transported them to Norway.

From 1840 to 1949 , Chinese cultural heritage was lost in amazing figures, calculated in millions of pieces, including hundreds of thousands of works of superb quality, scattered over 47 countries. ${ }^{22}$ Britain has the richest collection of Chinese cultural objects, next comes France. It is estimated that the British Museum has around 23,000 cultural heritage objects, including Chinese paintings and calligraphy, ancient books, jade, porcelain and bronze dating from different historical periods. ${ }^{23}$ In Guimet museum, over half of the works collected are of Chinese origin, more than 30,000 pieces in number. ${ }^{24}$ The US is another destination for a great deal of the lost Chinese paintings and calligraphy. It is estimated that the Freer Gallery alone has a collection of over 1,200 paintings and the Metropolitan Museum of Art owns more than 500 pieces. $^{25}$

All of this loss and the taking of Chinese cultural heritage have made the return all the more important and meaningful. China has begun insisting on asserting its interests over cultural heritage removed during this period. In the auction case of 2009, China's State Administration of Cultural Heritage stated that:

China does not acknowledge what it called the illegal possession of the two sculptures and would continue to seek the return of looted and/or stolen cultural objects and other illegally exported relics by all means in accordance with relevant international conventions and Chinese laws. ${ }^{26}$

21 Bree Feng, 'Despite Frigid Relations, Chinese Relics Coming Home From Norway', New York Times February 122014 <http://sinosphere.blogs.nytimes.com/2014/02/09/ despite-frigid-relations-chinese-relics-coming-home-from-norway/?_r $=0>$.

22 'Chinese Experts Demand Return of Cultural Relics' in Lyndel Prott (ed), Witnesses to History (UNESCO, 2008) 119, 119.

23 'Give Us Back Our Treasure', above n 9.

24 Irini A. Stamatoudi, Cultural Property Law and Restitution: A Commentary to International Conventions and European Union law (Edward Elgar Publishing, 2011), 25.

25 'Culture Insider: Chinese Cultural Relics Lost Overseas', China Daily Ausgust 152014 <www.chinadaily.com.cn/culture/art/2014-08/15/content_18311574.htm>.

26 'China Condemns Christie's Sculpture Sale, Warns of "Serious Effects"', Xinbua News February $262009<$ http://news.xinhuanet.com/english/2009-02/26/content_10900 960. htm>. 


\section{Introduction}

However, when the Chinese Government made this statement, it did not refer to a specific law that entitles China to claim for the return of the disputed art treasures. On the other hand, to obtain the return of removed heritage, repatriation cases have suggested that the first legal question China needs to deal with is to prove that China has a legal basis for the recovery.

Although international legal instruments, such as the 1954 Hague Convention, ${ }^{27}$ the 1970 UNESCO Convention ${ }^{28}$ and the 1995 UNIDROIT Convention, ${ }^{29}$ which provide for the restitution of cultural heritage, have emerged over the last 70 years, they do not apply retroactively. Most historical events, for example the Looting of the Summer Palace, that have given rise to current restitution claims occurred before the promulgation of such measures. Thus, one of the fundamental reasons for disputes being unresolved is that there was no law contemporaneous to the removal regulating such taking as illegal. In other words, current possessors are under no legal obligation to return. The usual result for the recovery claims is that enforceable legal action is not an option, resulting in an unsatisfying outcome both legally and ethically.

\section{Increasing Demand for Return, but Lacking a Legal Basis}

China is not the only country that has been active in pursuing the return of its cultural heritage. In the past few decades, other states of origin have been expecting the return of their cultural heritage: Greece has been requesting the return of the Parthenon Marbles for decades; South Korea has been requesting the return of its Ugiew, the historical books about its Joseon Dynasty (1392-1910); Egypt has been seeking the return of the Rosetta Stone and Nefertiti; and Nigeria has been demanding the return of the Benin bronzes. In many situations, in order to bring their heritage home, many states of origin have taken legal action against current possessors. Turkey petitioned the European Court of Human Rights for the return of the Helicarnassus; Italy took legal action against Marion True, the former curator of the Getty Museum, which was revealed to have accepted stolen Italian cultural objects; and Cambodia requested the US Government to apply civil forfeiture for the return of Khmer statues. As commented by a Turkish archaeologist, "we know

27 Convention for the Protection of Cultural Property in the Event of Armed Conflict (1954 Hague Convention). The Convention was completed by the Protocol for the Protection of Cultural Property in the Event of Armed Conflict (First Protocol-May 14 1954, 249 UNTS 358) and Second Protocol to the Hague Convention for the Protection of Cultural Property in the Event of Armed Conflict (Second Protocol-March 26 1999, 38 ILM 769 (1999)).

28 Convention on the Means of Prohibiting and Preventing the Illicit Import, Export and Transfer of Ownership of Cultural Property (1970 UNESCO Convention).

29 Convention on Stolen or Illegally Exported Cultural Object (1995 UNIDROIT Convention). 
100 percent that these objects at the Met are from Anatolia. And we only want back what is rightfully ours." 30

However, the lack of law regulating such removals as illegal makes it difficult for the claims to be successful. In May 2015, Greece stated that it had ruled out taking legal action in its battle to reclaim the Parthenon marbles from the UK, which ended the legal battle in one of the world's most debated cultural disputes. ${ }^{31}$ Arguments for the return of the marbles have been made on both cultural and ethical grounds, and diplomatic efforts have been attempted since the mid-1980s. ${ }^{32}$ The case was brought before the UNESCO Intergovernmental Committee; however, very little progress has been made. The fundamental reason for the dispute being unresolved is that there is no law contemporaneous to the removal regulating such taking as illegal. Neither the British Government nor the British Museum is under any legal obligation to return the Parthenon marbles to Greece. ${ }^{33}$ In other words, claims for the return of relics without a legal basis are usually silenced or at best discussed, but very rarely facilitated.

In the absence of mandatory obligation, although return could still be trigged through diplomatic negation or voluntary donation, the fate of disputed cultural heritage is left to the current possessor to decide. The available practices demonstrate that relying on another party's goodwill is unpredictable and unrewarding. In 1978, the Netherlands handed over to Indonesia some colonial art treasures of cultural and historical significance; however, earlier requests from Indonesia related to a list of 10,000 objects. ${ }^{34}$ Therefore, an ethics discourse is ineffective and inadequate to prompt large-scale restitution. Both China and other states of origin need a stronger argument to claim for the return of their cultural heritage.

\section{Is a New Customary Rule Emerging?}

In the past two decades, an increasing number of cultural heritage objects have been returned to states of origin by governments, museums, and individuals throughout the world. In particular, many claims that had been largely

30 Dan Bilefsky, 'Seeking Return of Art, Turkey Jolts Museums', New York Times September 302012 <www.nytimes.com/2012/10/01/arts/design/turkeys-efforts-to-repatri ate-art-alarm-museums.html?pagewanted=all\&_r=0 $>$.

31 Helena Smith, 'Greece Drops Option of Legal Action in British Museum Parthenon Marbles Row', Guardian May 142015 <www.theguardian.com/artanddesign/2015/ may/13/greece-drops-option-legal-action-british-museum-parthenon-marbles-row $>$.

32 Michael Reppas, 'Deflowering of the Parthenon: A Legal and Moral Analysis on Why the Elgin Marbles Must be Returned to Greece' (1999) 9 Fordham Intellectual Property, Media and Entertainment Law Journal 911.

33 'UK Government Rejects Parthenon Marbles UNESCO Mediation', Elginism March 27 $2015<$ www.elginism.com/elgin-marbles/uk-government-rejects-parthenon-marblesunesco-mediation $/ 20150327 / 7859 />$.

34 Jos van Beurden, 'How to Break the Deadlock in the Debate About Colonial Acquisitions?' in Valentina Vadi and Hildegard Schneider (eds), Art, Cultural Heritage and the Market: Ethical and Legal Issues (Springer, 2014) 165, 167. 


\section{Introduction}

unsuccessful in the late 20th century have now been successfully negotiated and settled. In 2006, the Metropolitan Museum of Art stated that it would relinquish ownership of a 2,500-year-old Greek vase to Italy, reversing a position it had held for more than 30 years. ${ }^{35}$ In the case of Iran $v$ Wolfcarius, while the Iranian Government initiated legal action in the Belgian court in 1981 for the return of disputed art objects, the litigation was pending until December 2014. The court finally acknowledged the Iranian government's legal right to all the disputed cultural relics and ordered for them to be returned to Iran, more than 30 years after Iran first sued for the return. ${ }^{36}$ In 2011, Japan eventually returned to South Korea over 1,200 precious ancient royal manuscripts, known as the Uigwe collection, more than 100 years after they were taken to Japan. ${ }^{37}$ The evolving law and retuning cases strongly contribute to the idea that the interests of states of origin in their wrongfully removed cultural heritage have been increasingly respected and recognised. Based on the increasing recognition, this book argues that a new customary rule is emerging and will likely come into existence in the future. The proposed customary rule recognizes that the interests of states of origin in their wrongfully removed heritage should be respected and such heritage should be returned.

To argue for the proposed customary rule, this research critically examines the types of state practices that should be considered as relevant evidence for the formation of the customary rule. Against this background, it is timely to identify the types of return that will be analysed in the following chapters: (1) historically removed heritage; and (2) illegally removed cultural objects, which were removed either, (a) during armed conflicts; or (b) because of individual illegal behavior, such as theft, illicit excavation or illegal export during times of both war and peace. The reason that cultural heritage should be treated differently is that the legality of various types of legal removal is determined by different bodies of law. As for illegal removal due to war or occupation, the question remains as to whether the law of war prohibited such taking and provided for the return of cultural heritage afterwards. The illegal removal of cultural items by individuals during both times of war and peace is an issue due to the contravention of national laws. One further clarification is necessary for illegal removal due to individual behavior and its sub-categories: (1) stolen heritage and (2) illegally exported heritage. The difference is that a foreign court may be inclined to help an original owner recover stolen property, but will be reluctant to help a foreign government enforce its export

35 Randy Kennedy and Hugh Eakin, 'The Met, Ending 30-Year Stance, Is Set to Yield Prized Vase to Italy', New York Times February 32006 <www.nytimes.com/2006/02/03/ arts $/ 03$ muse.html>.

36 Janet Blake, International Cultural Heritage Law (Oxford University Press, 2015), 62-63.

37 Danielle Demetriou, 'Japan Returns Looted South Korean Documents to Homeland', Telegraph December 62011 <www.telegraph.co.uk/news/worldnews/asia/ japan/8937503/Japan-returns-looted-South-Korean-documents-to-homeland.html>. 
rules. ${ }^{38}$ In other words, even though an object may be classified as illegally exported, the illicit removal does not necessarily constitute an illegal import, as a state is not obliged to recognise and enforce a foreign state's export law in the absence of a treaty or bilateral agreement. ${ }^{39}$

Despite the increasing returns made throughout the world, it should be admitted that the fundamental reason for many successful repatriations is that the states of origin generally have a legal basis and strong evidence to convince the courts that the disputed objects were illegally removed. However, for historically removed heritage, the obstacle standing in the way of return is a lack of law regulating such taking as illegal. In order to argue for the proposed customary rule, the crux of this research is to link the return of illegally taken heritage to historically removed heritage. Thus, the central questions lying at the basis of this book are whether an increasing recognition of states of origin's interests can be in found in state practices when illegally removed heritage is returned, and whether such recognition is sufficient to create the proposed customary rule to support the return of historically removed heritage. The increasing recognition of the interests of states of origin in their wrongfully removed cultural heritage is the bridge between illegally removed heritage and historically removed heritage. If state practices suggest that illegally removed heritage should be returned, it may reflect an increasing recognition and respect for states of origin and therefore constitute strong evidence for the formation of the proposed customary rule. Once state practices have shown a uniform and general recognition of states of origin's interests, this proposed rule will be recognised as a new customary rule. In other words, it will create a legal basis for states of origin to claim for the return of their historically removed heritage against current possessors. There will be more than just a moral and ethical connection between removal and return.

However, a question may arise as to whether the proposed customary rule is an overly optimistic view. To create a new customary rule, it is essential that the states whose interests are "specially affected" by the proposed customary rule should be in favour of the creation of this rule. Put simply, the uniform state practice in the specially affected states is required. In this regard, although there is an increasing recognition that foreign states should have sufficient interests to argue for the return of their wrongfully removed heritage, the uniformity among specially affected states is still lacking. For example, unresolved recovery issues during the Second World War suggests the lack of concurrence of those particularly affected states with the proposed customary

38 James Gordley, 'The Enforcement of Foreign Law: Reclaiming One Nation's Cultural Heritage in Another Nation's Courts' in Francesco Francioni and James Gordley (eds), Enforcing International Cultural Heritage Law (Oxford University Press, 2013) 110, 110-118; Yunxia Wang, Cultural Heritage Law (The Commercial Press, 2012), 376-378.

39 Paul M. Bator, 'An Essay on the International Trade in Art' (1982) 34(2) Stanford Law Review 275, 287. 


\section{Is a New Customary Rule Emerging?}

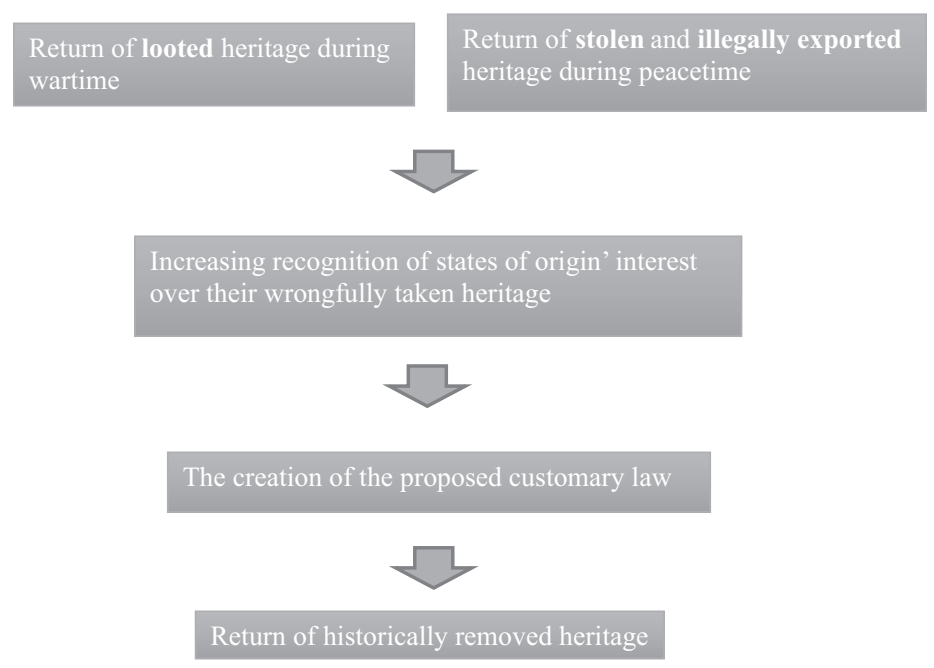

Figure 1.1

rule. Further, despite the return cases during the past two decades, actions by individuals and institutions do not constitute state behaviour and can therefore not create customary international law. More importantly, there is no indication that countries holding foreign cultural heritage removed in early times were willing to give them up at a large scale. All these issues raise uncertainty about the future of the proposed customary rule: whether the proposed customary rule can continue to develop, and eventually be recognised as a new customary rule.

\section{Book Scope}

Starting with the dispute surrounding the Chinese bronze statues, this book first aims to answer the question as to whether China has a legal basis to recover its cultural heritage taken during the period of 1840-1945. Although China has been expecting the return of its cultural heritage lost overseas, securing the return is problematic. Instead of pressing formal demands for repatriation, the approach used to bring scattered Chinese arts home is still limited to donation, buying-back, and diplomatic negotiation. ${ }^{40}$ The main rea-

40 Gao Sheng, 'Recovering Illegally Removed Cultural Property and Improving Cultural Property Protection: A Chinese Perspective' (2009) (1) Art Antiquity and Law 1, 9-14. 
son for this is that there is no clear answer as to whether China has a legal basis for the recovery. While many contributors have studied the topic of China's cultural heritage, they mostly focus on the cultural heritage law in the People's Republic of China (1949-present) and on other specific issues, including regulating the art market, preventing theft, illegal excavation and illegal export of cultural heritage, and promoting international cooperation. To the extent that these studies have considered the issue of the return of Chinese cultural heritage, they have focused on present day illegal trafficking of cultural objects instead of items that were looted before the founding of the People's Republic of China. Little research has been made on the applicable laws contemporaneous to removals that occurred during the period of 1840-1945, which is law in the Qing Dynasty (1644-1911) and law in the Republic of China (19111949). On the other hand, the question as to whether China has a legal basis for recovery is the first legal hurdle that China needs to get over. Thus, this research aims to examine the availability of a legal basis for the recovery of China's cultural heritage.

While the first part of the book is aimed at China specifically, the positioning of China in this book is not merely as a case study. This book is also valuable to all states that are active or involved in the field of restitution of cultural heritage. When ethics discourse is ineffective and inadequate in promoting large-scale restitution, the proposed customary rule will provide a solution. The proposed customary rule will allow not only China, but also other states of origin with a similar dilemma, to obtain the return of both illegally and historically removed heritage. In other words, all states of origin should have a right to the return of their wrongfully removed cultural heritage according to this proposed customary rule. China has been used as a case study in this book because of its experience with the process.

As it will be analysed, China does not have a legal basis for all cultural heritage taken during the period of 1840-1945, in which case the proposed customary rule may provide an answer. The second part of this book will answer questions about whether the proposed customary rule is emerging. Premised on the assumption that the new rule has come into existence, it will provide China and other states of origin a stronger and legal argument to claim against museums and art collectors for the return of cultural items. To argue for the proposed custom, this book provides a systematic and critical examination of the types of state practice that should be considered as relevant evidence for the formation of the customary rule. This book argues that the available state practice has shown a clear tendency towards supporting the return of wrongfully removed heritage.

Several further aspects necessitate clarification. First, this book focuses on the return of Chinese cultural heritage taken from the First Opium War to the end of the Japanese Occupation (1840-1945). The proposed timeframe (1840-1945) falls short of the period during which some of the most important Chinese material was relocated to Taiwan from the mainland by the Kuomintang. The reason that this book does not go beyond the date of 1945 is 


\section{Introduction}

the return of cultural heritage taken to Taiwan raises an entirely different set of issues and would be best left to another book in the future. ${ }^{41}$ Similar reasons apply to the ongoing illicit trafficking of stolen and smuggled cultural heritage in China. Although all these issues are of great importance for the management and protection of Chinese cultural heritage, they are beyond the discussion of this book, which primarily focuses on historically removed heritage.

Second, despite the different theories in terms of creating a new customary rule, this research adopts the ideas of Brownlie and Shaw, according to which the most crucial factor is the concurrence of specially affected states in that particular field. States whose interests are especially affected must belong to those endorsing the creation of the rule. In the field of restitution, specially affected states can be divided into two groups: current possessors, including the UK, the US, France, Japan, Germany, and Switzerland; and states of origin, such as China, Cambodia, Egypt, Greece, Italy, Turkey, and Peru. This book focuses on these specially affected states to argue that there is an increasing endorsement of the proposed customary rule.

Third, it should be further noted that what makes return legally complex is that it lies at the interface of a number of distinct branches of law: the law of war, private international law, human rights, cultural heritage law, and national laws (such as criminal law, property law, contract law, and tort law). These legal areas are quite different in nature, but form the basis for supporting the return of illegally removed heritage. This book will examine all the relevant laws that may form a basis for the return of wrongfully removed heritage.

Fourth, this book will not be limited to legal analysis, as the return of cultural heritage cannot be dealt with on a strictly legal argument alone. In the realm of cultural heritage, a wide range of guidelines, policies and other socalled soft laws have played an important role in facilitating the return of cultural heritage. Additionally, an increasing number of cultural objects have been returned to states of origin by private museums, non-governmental institutions, auction houses and individuals throughout the world. Although they do not constitute state behaviour and therefore cannot create customary international law, they are still worth discussing in this book, as the return of cultural heritage is not a theme that can be treated convincingly without a fully grounded engagement with ethics. The legal doctrinal discourse in this book is contextualised with reference to the moral arguments that support the return of wrongfully removed heritage.

41 For example, the return of cultural heritage to Taiwan is closely linked with the question as to whether "Taiwan is part of China's territory". The answer to this question is significant, as it will then determine the law applied to the question of removals' legality. According to the author, Taiwan is part of China's territory, which means the taking itself is an internal matter and should be governed by China's domestic law. However, others may have a different opinion and believe that Taiwan should be considered as an independent state. Therefore, the question of legality should be answered under the framework of public international law. 
While discussing materials of both state practice and non-state practice, this book is significant and valuable to museums and art collectors in the event of buying and accepting art objects. First, this book deals with a large pool of repatriation cases and compares all available solutions, including litigation, negotiation, cooperation, buying-back, conditional return, art loan, donation, or simply stepping up the pressure. A problem-sensitive, practical approach is provided. Though this comparative study, the book provides a useful tool for a disputing party, including museums, art collectors, auction houses, and governments, to settle cultural disputes peacefully and to avoid unnecessary negative headlines, reputational damage or the impoverishment of their collections. In particular, through the systematic analysis of different branches of law in specially affected states, this book provides some suggestions on how museums, art collectors and auction houses should buy and accept foreign art, in case of getting embroiled in a dispute with a foreign government. Furthermore, from the perspective of cultural heritage law, this book is also structured on three categories of cultural heritage: (1) heritage looted during armed conflicts; (2) heritage stolen, illegally excavated, or illegally exported in peacetime; (3) and historically taken heritage. By examining the evolving cultural heritage law, this book is significant in suggesting the protection and management of cultural heritage, which will eventually have an impact on the art market, museums and art collections.

\section{Chapter Summary}

After this introductory chapter, the book is structured in the following ways. Chapter 2 investigates the long-lasting legal, moral and societal debates surrounding the allocation of cultural heritage. This chapter argues that although cultural heritage should be available to and protected by all humankind, it should be conducted in a reasonable way and respect the will of the people from states of origin. Cultural heritage that was removed against the will of the original owners should be returned due to the special and strong connection between states of origin and their cultural heritage.

Chapter 3 focuses on the legal grounds that exist for China to request the return of its cultural heritage in order to determine whether the taking of objects during 1840 to 1949 was prohibited under either China's national law or international law. This chapter concludes that China does not have a basis for the return of all removals that occurred between 1840 and 1945, and, in these cases, the customary rule may provide an answer. This chapter ends with a discussion about the definition of historically removed heritage and its return, which is the fundamental question that this book aims to resolve.

With regards to the creating of a new customary rule, there is considerable academic debate as to whether and when a new rule can be accepted as a customary rule. Chapter 4 explores the notion of customary international law and the process of creating a new customary rule. This chapter argues that the 


\section{4}

most crucial factor is the concurrence of "specially affected" states in the field of the removal and return of cultural heritage.

The following two chapters focus on the two premises needed to create the proposed customary rule: the return of looted heritage during wartime; and the return of stolen and illegally exported heritage in peacetime respectively. Chapter 5 examines the evolving international law and practice regarding the prohibitation of looting of cultural heritage during wartimes and the repatriation of removed arts after the end of war. This chapter argues that specially affected states have shown an increasing agreement that cultural heritage looted, stolen or illegally exported during wartime should be returned. However, the unresolved issues of war repatriations during the two world wars have constituted a powerful deterrent to the creation of the proposed customary rule.

Chapter 6 discusses the restitution of stolen and illegally exported arts taken during peacetime. This chapter examines international law, European law, as well as laws in the market states, including the US, Germany, Switzerland, the UK and the Netherlands. This chapter reaches the conclusion that state practice has shown a growing recognition that stolen and illegally exported cultural objects should be returned to states of origin. However, the lack of uniformity suggests that the proposed customary rule is at the very beginning of the process of its formation.

Chapter 7 focuses on the practice of individuals, private museums and auction houses, in order to explore whether there is increasing public endorsement for the return of wrongfully removed heritage and moral acknowledgment of claims by the states of origin. Although they do not constitute state behaviour, they are still a noteworthy issue, as public attitudes and ethical considerations generally precede the development of legal rules. In other words, they are important in suggesting whether the proposed customary rule is likely to come into existence. Additionally, the return of cultural heritage is not a theme that can be treated convincingly without a fully grounded engagement with ethics.

Chapter 8 first examines three return cases of historically removed heritage, which show that a dialogue about the future of historically removed objects is complicated and will not be a quick-fix. This concluding chapter then answers the final question as to whether a new rule of customary international law is emerging, to the effect that historically removed cultural heritage should be returned to states of origin; and, if such a rule is emerging, what are the likely limitations to this rule.

\section{Bibliography}

'China Condemns Christie's Auction', The BBC News February 262009 <http:// news.bbc.co.uk/2/hi/asia-pacific/7911691.stm>

'China Condemns Christie's Sculpture Sale, Warns of "Serious Effects"', Xinhua News February 262009 <http://news.xinhuanet.com/english/2009-02/26/ content_10900960.htm> 
'China Tightens Control on Christie's After Auction', The Xinhua News February 26 2009 <http://news.xinhuanet.com/english/2009-02/26/content_10901300. htm>

'Chinese Experts Demand Return of Cultural Relics' in Lyndel Prott (ed), Witnesses to History (UNESCO, 2008) 119

'Culture Insider: Chinese Cultural Relics Lost Overseas', China Daily August 15 $2014<w w w . c h i n a d a i l y . c o m . c n / c u l t u r e / a r t / 2014-08 / 15 / c o n t e n t \_18311$ 574.htm>

" "Give Us Back Our Treasure": Chinese Demand Cameron Returns Priceless Artefacts Looted during 19th Century Boxer Rebellion', Mail Online December 42013 <www.dailymail.co.uk/news/article-2518111/China-demandDavid-Cameron-return-Boxer-Rebellion-artefacts.html>

'UK Government Rejects Parthenon Marbles UNESCO Mediation', Elginism March 272015 <www.elginism.com/elgin-marbles/uk-government-rejectsparthenon-marbles-unesco-mediation/20150327/7859/>

'War Damage on Cultural Relics Commission under the Department of Education', China Cultural Relics August 222007 <www.xhgxt.com/html/ View_9270.html>

Bator, Paul M., 'An Essay on the International Trade in Art' (1982) 34(2) Stanford Law Review 275

Beurden, Jos van, 'How to Break the Deadlock in the Debate About Colonial Acquisitions?' in Valentina Vadi and Hildegard Schneider (eds), Art, Cultural Heritage and the Market: Ethical and Legal Issues (Springer, 2014) 165

Bilefsky, Dan, 'Seeking Return of Art, Turkey Jolts Museums', New York Times September 302012 <www.nytimes.com/2012/10/01/arts/design/turkeysefforts-to-repatriate-art-alarm-museums.html?pagewanted=all\&_r=0>

Blake, Janet, International Cultural Heritage Law (Oxford University Press, 2015)

Changhong, Yan and Li Xia, 'A Review of Japan's Cultural Aggression against China during Anti-Japanese War' (in Chinese) (2005) 25(4) Journal of SouthCentral University for Nationalities (Humanities and Social Sciences) 12

Cuno, James, Who Owns Antiquity?: Museums and the Battle over Our Ancient Heritage (Princeton University Press, 2008)

Demetriou, Danielle, 'Japan Returns Looted South Korean Documents to Homeland', Telegraph December 62011 <www.telegraph.co.uk/news/worldnews/ asia/japan/8937503/Japan-returns-looted-South-Korean-documents-tohomeland.html>

Fairbank, John King, The Cambridge History of China Volume 10: Late Ch'ing 1800-1911, Part 1 (Cambridge University Press, 1978)

Gordley, James, 'The Enforcement of Foreign Law: Reclaiming One Nation's Cultural Heritage in Another Nation's Courts' in Francesco Francioni and James Gordley (eds), Enforcing International Cultural Heritage Law (Oxford University Press, 2013) 110

Gruber, Stefan, 'The Fight Against the Illicit Trade in Asian Cultural Artefacts: Connecting International Agreements, Regional Co-operation, and Domestic strategies' (2013) 3(2) Asian Journal of International Law 341

Kennedy, Randy and Hugh Eakin, 'The Met, Ending 30-Year Stance, Is Set to Yield Prized Vase to Italy', New York Times February 32006 <www.nytimes. com/2006/02/03/arts/03muse.html> 


\section{Introduction}

Kowalski, Wojciech, 'Types of Claims for Recovery of Lost Cultural Property' (2005) 57(228) Museum International 85

Liu, Zuozhen, The Case for Repatriating China's Cultural Objects (Springer, 2016)

Meyer, Karl, 'The Chinese Want Their Art Back', New York Times June 202015 <www.nytimes.com/2015/06/21/opinion/the-chinese-want-their-art-back. html?_r=0>

Peng, Lei, A Research on Legal History of Return of Relics (in Chinese) (Nanjing: Yilin Publishing, 2012)

Perez, Louis G., Japan at War: An Encyclopedia (ABC-CLIO, 2013)

Prott, Lyndel and Patrick O'Keefe, “"Cultural Heritage” or "Cultural Property"? (1992) 1(2) International Journal of Cultural Property 307

Reppas, Michael, 'Deflowering of the Parthenon: A Legal and Moral Analysis on Why the Elgin Marbles Must be Returned to Greece' (1999) 9 Fordham Intellectual Property, Media and Entertainment Law Journal 911

Scott, David, China and the International System, 1840-1949: Power, Presence, and Perceptions in A Century of Humiliation (State University of New York Press, 2008)

Sheng, Gao, 'Recovering Illegally Removed Cultural Property and Improving Cultural Property Protection: A Chinese Perspective' (2009) (1) Art Antiquity and Law 1

Smith, Helena, 'Greece Drops Option of Legal Action in British Museum Parthenon Marbles Row', Guardian May 142015 <www.theguardian.com/ artanddesign/2015/may/13/greece-drops-option-legal-action-british-museumparthenon-marbles-row $>$

Stamatoudi, Irini A., Cultural Property Law and Restitution: A Commentary to International Conventions and European Union law (Edward Elgar Publishing, 2011)

Wang, Yunxia, Cultural Heritage Law (The Commercial Press, 2012)

Wong, Edward and Steven Erlanger, 'Frenchman Will Return to China Prized Bronze Artifacts Looted in 19th Century', The New York Times April 262013 <www.nytimes.com/2013/04/27/world/europe/frenchman-will-return-tochina-prized-bronze-artifacts-looted-in-19th-century.html>

Zhang, Yu, 'France Returning Treasure to China Sets Precedent for Further Restitutions', Global Times September 92015 <www.globaltimes.cn/con tent/941506.shtml> 


\section{Introduction}

'China Condemns Christie's Auction', The BBC News February 262009

<http://news.bbc.co.uk/2/hi/asia-pacific/7911691.stm>

'China Condemns Christie's Sculpture Sale, Warns of “Serious Effects"', Xinhua News

February 262009 <http://news.xinhuanet.com/english/2009-02/26/content_10900960.htm>

'China Tightens Control on Christie's After Auction', The Xinhua News February 262009

<http://news.xinhuanet.com/english/2009-02/26/content_10901300.htm>

'Chinese Experts Demand Return of Cultural Relics' in Lyndel Prott (ed), Witnesses to History

(UNESCO, 2008) 119

'Culture Insider: Chinese Cultural Relics Lost Overseas', China Daily August 152014

<www.chinadaily.com.cn/culture/art/2014-08/15/content_18311574.htm>

"'Give Us Back Our Treasure": Chinese Demand Cameron Returns Priceless Artefacts

Looted during 19th Century Boxer Rebellion', Mail Online December 42013

$<$ www.dailymail.co.uk/news/article-2518111/China-demand-David-Cameron-return-Boxer-

Rebellion-artefacts.html>

'UK Government Rejects Parthenon Marbles UNESCO Mediation', Elginism March 272015

$<$ www.elginism.com/elgin-marbles/uk-government-rejects-parthenon-marbles-unescomediation/20150327/7859/>

'War Damage on Cultural Relics Commission under the Department of Education', China Cultural Relics August 222007 <www.xhgxt.com/html/View_9270.html>

Bator, Paul M. , 'An Essay on the International Trade in Art' (1982) 34(2) Stanford Law Review 275

Beurden, Jos van , 'How to Break the Deadlock in the Debate About Colonial Acquisitions?' in Valentina Vadi and Hildegard Schneider (eds), Art, Cultural Heritage and the Market:

Ethical and Legal Issues (Springer, 2014) 165

Bilefsky, Dan , 'Seeking Return of Art, Turkey Jolts Museums', New York Times September 302012 <www.nytimes.com/2012/10/01/arts/design/turkeys-efforts-to-repatriate-art-alarmmuseums.html?pagewanted=all\&_r=0>

Blake, Janet, International Cultural Heritage Law (Oxford University Press, 2015)

Changhong, Yan and Li Xia , 'A Review of Japan's Cultural Aggression against China during Anti-Japanese War' (in Chinese) (2005) 25(4) Journal of South-Central University for

Nationalities (Humanities and Social Sciences) 12

Cuno, James, Who Owns Antiquity?: Museums and the Battle over Our Ancient Heritage

(Princeton University Press, 2008)

Demetriou, Danielle , 'Japan Returns Looted South Korean Documents to Homeland',

Telegraph December 62011

$<$ www.telegraph.co.uk/news/worldnews/asia/japan/8937503/Japan-returns-looted-South-

Korean-documents-to-homeland.html>

Fairbank, John King , The Cambridge History of China Volume 10: Late Ch'ing 1800-1911,

Part 1 (Cambridge University Press, 1978)

Gordley, James , 'The Enforcement of Foreign Law: Reclaiming One Nation's Cultural

Heritage in Another Nation's Courts' in Francesco Francioni and James Gordley (eds),

Enforcing International Cultural Heritage Law (Oxford University Press, 2013) 110

Gruber, Stefan, 'The Fight Against the Illicit Trade in Asian Cultural Artefacts: Connecting

International Agreements, Regional Co-operation, and Domestic strategies' (2013 3(2) Asian

Journal of International Law 341

Kennedy, Randy and Hugh Eakin, 'The Met, Ending 30-Year Stance, Is Set to Yield Prized Vase to Italy', New York Times February 32006

<www.nytimes.com/2006/02/03/arts/03muse.html>

Kowalski, Wojciech , 'Types of Claims for Recovery of Lost Cultural Property' (2005 57(228)

Museum International 85

Liu, Zuozhen, The Case for Repatriating China's Cultural Objects (Springer, 2016)

Meyer, Karl , 'The Chinese Want Their Art Back', New York Times June 202015

<www.nytimes.com/2015/06/21/opinion/the-chinese-want-their-art-back.html?_r=0>

Peng, Lei , A Research on Legal History of Return of Relics (in Chinese) (Nanjing: Yilin

Publishing, 2012) 
Perez, Louis G. , Japan at War: An Encyclopedia (ABC-CLIO, 2013)

Prott, Lyndel and Patrick O'Keefe , 'Cultural Heritage" or "Cultural Property"?' (1992 1(2) International Journal of Cultural Property 307

Reppas, Michael , 'Deflowering of the Parthenon: A Legal and Moral Analysis on Why the Elgin Marbles Must be Returned to Greece' (1999) 9 Fordham Intellectual Property, Media and Entertainment Law Journal 911

Scott, David, China and the International System, 1840-1949: Power, Presence, and Perceptions in A Century of Humiliation (State University of New York Press, 2008)

Sheng, Gao , 'Recovering Illegally Removed Cultural Property and Improving Cultural Property Protection: A Chinese Perspective' (2009) (1) Art Antiquity and Law 1

Smith, Helena, 'Greece Drops Option of Legal Action in British Museum Parthenon Marbles Row', Guardian May 142015 <www.theguardian.com/artanddesign/2015/may/13/greecedrops-option-legal-action-british-museum-parthenon-marbles-row>

Stamatoudi, Irini A. , Cultural Property Law and Restitution: A Commentary to International Conventions and European Union law (Edward Elgar Publishing, 2011)

Wang, Yunxia, Cultural Heritage Law (The Commercial Press, 2012)

Wong, Edward and Steven Erlanger , 'Frenchman Will Return to China Prized Bronze

Artifacts Looted in 19th Century', The New York Times April 262013

$<$ www.nytimes.com/2013/04/27/world/europe/frenchman-will-return-to-china-prized-bronzeartifacts-looted-in-19th-century.html>

Zhang, Yu , 'France Returning Treasure to China Sets Precedent for Further Restitutions', Global Times September 92015 <www.globaltimes.cn/content/941506.shtml>

\section{States of Origin and Cultural Heritage}

'Ambassadors Fund for Cultural Preservation (AFCP): Nepal Projects (Bureau of Educational and Cultural Affairs Promoting Mutual Understanding <http://eca.state.gov/cultural-heritagecenter/gallery/ambassadors-fund-cultural-preservation-afcp-nepal-projects>

'China Condemns Christie's Auction', The BBC News February 262009

<http://news.bbc.co.uk/2/hi/asia-pacific/7911691.stm>

'China Reserves Right to Recover Illegally Looted Cultural Relics', Xinhua News November 5 2016 <http://news.xinhuanet.com/english/2016-11/05/c_135806933.htm>

'Chinese Pillars are Being Transferred', KODE Art Museums of Bergen

$<$ http://kodebergen.no/en/article/chinese-pillars-are-being-transferred>

'Christie's Auction Controversy Reveals China's Dilemma In Retrieving Lost Relics', Xinhua News February 162009 <http://news.xinhuanet.com/english/2009-

02/16/content_10829310.htm>

'The Efforts to Bid for or Purchase Any Chinese Treasures that Have Been Plundered, Stolen or Illegally Exported are not Encouraged', Wenwu China November 22010

$<$ www.wenwuchina.com/news/list7/detail37/71320.html>

'Global Chinese Art Auction Market Report 2015', Artnet <www.cn.artnet.com/en/chinese-artauction-market-report/>

'Help Stop the Destruction of Cultural Heritage in Syria and Iraq' (UNESCO)

$<$ www.unesco.org/new/en/culture/themes/illicit-trafficking-of-cultural-property/awareness-

raising-initiatives/help-stop-the-destruction-of-cultural-heritage-in-syria-and-iraq/>

'More Than 10 Million Chinese Cultural Relics Lost Overseas' (2007 People's Daily

<http://english.people.com.cn/200701/30/eng20070130_345934.html>

'Often Asked Questions' (KODE Art Museums of Bergen)

$<$ http://kodebergen.no/en/article/often-asked-questions>

'Parthenon Echoes', Guardian March 282002

<www.theguardian.com/news/2002/mar/28/leadersandreply.mainsection>

'Publication of Collective Documents on the Confessions of Japanese War Criminals by the

State Archives Administration (Issue 2)' (State Administration of Cultural Heritage)

<www.sach.gov.cn/art/2017/7/21/art_722_142657.html> 
'Re-building Cultural Heritage in Mali', UNESCO, July 12014

$<$ www.unesco.org/new/en/unesco-liaison-office-in-new-york/about-this-office/singleview/news/re_building_cultural_heritage_in_mali/>

Abungu, George , 'The Declaration: A Contested Issue' in Lyndel Prott (ed), Witnesses to History (UNESCO, 2009) 121

Amineddoleh, Leila , 'The British Museum Should Return The Parthenon Marbles To Greece', Forbes December 232014 <www.forbes.com/sites/realspin/2014/12/23/the-british-museumshould-return-the-parthenon-marbles-to-greece/>

Barboza, David, Graham Bowley and Amanda Cox, 'Forging an Art Market in China', New York Times October 282013 <www.nytimes.com/projects/2013/china-art-fraud/>

Barkan, Elazar , 'Amending Historical Injustices: The Restitution of Cultural Property-An Overview' in Claiming the Stones, Naming the Bones: Cultural Property and the Negotiation of National and Ethnic Identity (Getty Research Institute, 2002) 16

Benjamin, Walter, The Work of Art in the Age of Mechanical Reproduction (transl. J.A. Underwood ) (Penguin, 2008)

Castells, Manuel, Power of Identity: The Information Age: Economy, Society, and Culture Volume II (Wiley-Blackwell, 2009)

Chen, Jianfu, Chinese Law: Context and Transformation (Martinus Nijhoff Publishers, 2008) Cuno, James, Who Owns Antiquity?: Museums and the Battle over Our Ancient Heritage (Princeton University Press, 2008)

Feng, Bree, 'Despite Frigid Relations, Chinese Relics Coming Home From Norway', New York Times February 122014 <http://sinosphere.blogs.nytimes.com/2014/02/09/despitefrigid-relations-chinese-relics-coming-home-from-norway/? $r=0>$

Forrest, Craig , International Law and The Protection of Cultural Heritage (Routledge, 2010) Gao, Sheng , 'International Protection of Cultural Property: Some Preliminary Issues and the Role of International Conventions' (2008 12 Singapore Year Book of International Law 57 Gonzalez, MA , 'New Legal Tools to Curb the Illicit Traffic in Pre-Columbian Antiquities' (1973 12(2) Columbia Journal of Transnational Law 316

Harrison, James, Modern Chinese Nationalism (Hunter College of the City University of New York, 1969)

Hung, Wu , 'The Admonitions Scroll Revisited: Iconology, Narratology, Style, Dating' in Shane McCausland (ed), Gu Kaizhi and the Admonitions Scroll (British Museum Press, 2003) 89

Jessop, Sonia Kolesnikov , 'Toning Down the Bling Factor', The New York Times September 102012 <www.nytimes.com/2012/09/11/business/global/toning-down-the-bling-factor.html>

Jote, Kifle , International Legal Protection of Cultural Heritage (Juristforlaget, 1994)

Jower, Kevin , 'Comment: International and National Legal Efforts to Protect Cultural Property: The 1970 UNESCO Convention, the United States, and Mexico' (2003 38 Texas International Law Journal 145

Lanciotti, Alessandra , 'The Dilemma of the Right to Ownership of Underwater Cultural Heritage: The Case of the "Getty Bronze"' in Silvia Borelli and Federico Lenzerini (eds), Cultural Heritage, Cultural Rights, Cultural Diversity: New Developments in International Law (Martinus Nijhoff Publishers, 2012) 301

Liu, Zuozhen , The Case for Repatriating China's Cultural Objects (Springer, 2016)

Loulanski, Tolina , 'Revising the Concept for Cultural Heritage: The Argument for a Functional Approach' (2006 13(2) International Journal of Cultural Property 207

Lu, Martin and Rosita Dellios , 'One Culture Two Systems: A Cultural Approach to InterChinese Politics' 3(1) Culture Mandala: The Bulletin of the Centre for East-West Cultural and Economic Studies 18

MacFarquhar, Roderick and John King Fairbank, The Cambridge History of China. Vol. 15, The People's Republic. Part 2, Revolutions within the Chinese Revolution, 1966-1982 (Cambridge University Press, 2008)

Manhart, Christian , 'UNESCO's Mandate and Recent Activities for the Rehabilitation of Afghanistan's Cultural Heritage' (2004 86(854) International Review of the Red Cross 401 Merryman, John Henry , 'Cultural Property Internationalism' (2005 12(1) International Journal of Cultural Property 11 
Merryman, John Henry , Imperialism, Art and Restitution (Cambridge University Press, 2006) Murphy, David, Plunder and Preservation: Cultural Property Law and Practice in the People's Republic of China (Oxford University Press, 1995)

O'Keefe, Patrick , 'Repatriation of Sacred Objects' in Lyndel Prott (ed), Witnesses to History: A Compendium of Documents and Writings on the Return of Cultural Objects (UNESCO, 2009)

Perlez, Jane , 'Christie's Opens for Business in Mainland China With Its First Auction', New York Times September 262013 <http://artsbeat.blogs.nytimes.com/2013/09/26/christiesopens-for-business-in-mainland-china-with-its-first-auction/>

Perlez, Jane and Bree Feng , 'Chinese Group Calls on Japan to Hand Over Tang- Era Stele', New York Times August 212014 <http://sinosphere.blogs.nytimes.com/2014/08/21/chinesegroup-calls-on-japan-to-hand-over-tang-era-stele/>

Posner, Eric , 'The International Protection of Cultural Property: Some Skeptical

Observations' (2007 8(1) Chicago Journal of International Law 213

Potter, Leslie and Bruce Zagaris , 'Toward a Common US-Mexican Cultural Heritage: The Need for a Regional Americas Initiative in the Recovery and Return of Stolen Cultural Property' (1992 5 Transnational Law 627

Prott, Lyndel , 'The International Movement of Cultural Objects' (2005 12(2) International Journal of Cultural Property 225

Ramzy, Austin , 'Xi Condemns Efforts to Play Down Japan's Wartime Aggression', New York Times July 72014 <http://sinosphere.blogs.nytimes.com/2014/07/07/xi-condemns-efforts-toplay-down-japans-wartime-aggression/>

Rong Xinjiang, Translated by: Imre Galambos , Eighteen Lectures on Dunhuang (Brill, 2013) Schorlemer, Sabine von, 'Legal Changes in the Regime of the Protection of Cultural Property in Armed Conflict' (2004 ix(1) Art Antiquity and Law 43

Shedwill, Jamison , 'Is the "Lost Civilization" of the Maya Lost Forever?: The US and Illicit Trade in Pre-Columbian Artifacts' (1992 23(1) California Western International Law Journal 227

Shyllon, Folarin , 'Unraveling History: Return of African Cultural Objects Repatriated and Looted in Colonial Times' in James A.R. Nafziger and Ann Nicgorski (eds), Cultural Heritage Issues (Martinus Nijhoff Publishers, 2009) 159

Smith, Helena , 'Parthenon Marbles: Greece Furious over British Loan to Russia', Guardian December 62014 <www.theguardian.com/artanddesign/2014/dec/05/parthenon-marblesgreece-furious-british-museum-loan-russia-elgin>

Stamatoudi, Irini A. , Cultural Property Law and Restitution: A Commentary to International Conventions and European Union Law (Edward Elgar Publishing, 2011)

Weiner, Annette , 'Inalienable Wealth' in Simon Knell (ed), Museums in the Material World (Routledge, 2007) 253

Wong, Edward and Steven Erlanger , 'Frenchman Will Return to China Prized Bronze Artifacts Looted in 19th Century', The New York Times April 262013

$<$ www.nytimes.com/2013/04/27/world/europe/frenchman-will-return-to-china-prized-bronzeartifacts-looted-in-19th-century.html>

Zhong, Hui , 'China's New Law on Art Auction' (2017 XXII(3) Art Antiquity and Law 220

\section{Availability of a Legal Basis for the Return of China's Cultural Heritage}

'Experts Urge Collectors To Share World's Earliest Encyclopedia', China.org.cn April 172002 $<$ http://china.org.cn/english/PP-e/31248.htm>

'Joint Communique of the Government of Japan and the Government of the People's Republic of China' (1972 Ministry of Foreign Affairs of Japan <www.mofa.go.jp/region/asiapaci/china/joint72.html>

'The Qing East Imperial Tombs', Chinaorg

<www.china.org.cn/english/features/atam/115430.htm> 
'Responsibility of States for Internationally Wrongful Acts' (United Nations) <http://legal.un.org/ilc/texts/instruments/english/draft_articles/9_6_2001.pdf>

'War Damage on Cultural Relics Commission under the Department of Education', China Cultural Relics August 222007 <www.xhgxt.com/html/View_9270.html>

Afjochnick, Chris and Roger Normand, 'The Legitimation of Violence: A Critical Historical of the Laws of War' (1994 35(1) Harvard International Law Journal 49

Arkell, Roland, 'Christie's Face Chinese Threats as Buyer Refuses to Pay', Antiques Trade Gazette March 92012

$<$ www.antiquestradegazette.com/news/2009/mar/09/christie\%E2\%80\%99s-face-chinese-

threats-as-buyer-refuses-to-pay/>

Aust, Anthony, Handbook of International Law (Cambridge University Press, 2005)

Best, Geoffrey , Humanity in Warfare: The Modern History of the International Law of Armed Conflicts (Weidenfeld and Nicolson, 1980)

Blake, Janet , International Cultural Heritage Law (Oxford University Press, 2015)

Bos, Adriaan, 'The Importance of the 1899, 1907 and 1999 Hague Conferences for the Legal

Protection of Cultural Property in the Event of Armed Conflict' (2005 57(4) Museum

International 32

Cameron, Meribeth , The Reform Movement in China, 1898-1912 (AMS Press, 1974)

Chen, Jianfu , Chinese Law: Context and Transformation (Martinus Nijhoff Publishers, 2008)

China, National Museum of, 'Pictorial Bricks'

<http://en.chnmuseum.cn/Default.aspx?Tabld=557\&HotType=46\&AspxAutoDetectCookieSup port=1>

Cohen, Jerome Alan , R. Randle Edwards and Fu-mei Chang Chen , Essays on China's

Legal Tradition (Princeton University Press, 1980)

Darby, H.C. , 'The Chinese Legal and Political system: Historical Background' in Kathryn

Bernhardt and Philip C. C. Huang (eds), Civil law in Qing and Republican China (Stanford

University Press, 1994)

Ding, James, 'China' in James A.R. Nafziger and Robert Kirkwood Paterson (eds),

Handbook on the Law of Cultural Heritage and International Trade (Edward Elgar Publishing, 2014) 107

Downey, William Gerald, 'Captured Enemy Property: Booty of War and Seized Enemy

Property' (1950 44(3) The American Journal of International Law 488

Edmonds, James Edward and Lassa Oppenheim , Land Warfare (HM Stationery Office, 1912)

Feng, Yulan and Derk Bodde , A Short History of Chinese Philosophy (Free Press, 1966)

Forrest, Craig , International Law and The Protection of Cultural Heritage (Routledge, 2010)

Friedman, Leon, The Law of War: A Documentary History (Random House, 1972)

Graduate Institute of History, The Academia Sinica 'The archives of the Grand Secretariat'

$<$ http://archive.ihp.sinica.edu.tw/mctkm2/index.html>

Janis, Mark W. , International Law (Wolters Kluwer Law \& Business, 5th ed, 2012)

Jiang, Yonglin , The Great Ming Code: Da Ming Lü (University of Washington Press, 2005)

Jote, Kifle , International Legal Protection of Cultural Heritage (Juristforlaget, 1994)

Liu, Zuozhen , The Case for Repatriating China's Cultural Objects (Springer, 2016)

Loucaides, Loukis G. , 'The Protection of the Right to Property in Occupied Territories' (2004 53(3) The International and Comparative Law Quarterly 677

MacCormack, Geoffrey, The Spirit of Traditional Chinese Law (University of Georgia Press, 1996)

MacCormack, Geoffrey , Traditional Chinese Penal Law (Edinburgh University Press, 1990)

Murphy, David, Plunder and Preservation: Cultural Property Law and Practice in the

People's Republic of China (Oxford University Press, 1995)

Nahlik, Stanislaw E. , 'International Law and The Protection of Cultural Property in Armed Conflicts' (1975 27 Hastings Law Journal 1069

O'Keefe, Patrick , 'Repatriation of Sacred Objects' in Lyndel Prott (ed), Witnesses to History:

A Compendium of Documents and Writings on the Return of Cultural Objects (UNESCO,

2009) 
O'Keefe, Roger , The Protection of Cultural Property in Armed Conflict (Cambridge University Press, 2006)

Palmer, Norman , 'Fetters and Stumbling Blocks: Impediments to the Recovery and Return of Unlawfully Removed Cultural Objects-A Common Law Perspective' in Lyndel. V. Prott . (ed), Realising Cultural Heritage Law: Festschrift for Patrick O'Keefe (Institute for Art and Law, 2012) 97

Poulos, Anthi Helleni , 'The 1954 Hague Convention for the Protection of Cultural Property in the Event of Armed Conflict: An Historic Analysis' (2000 28(1) International Journal of Legal Information 1

Prott, Lyndel , 'Problems of Private International Law for the Protection of the Cultural Heirtage' in Hague Academy of International Law (ed), Collected Courses of the Hague Academy of International Law (Nijhoff, 1989) 215

Schindler, Dietrich and Jiri Toman , The Laws of Armed Conflicts: A Collection of

Conventions, Resolutions, and Other Documents (Martinus Nijhoff Publishers, 2004)

Second Historical Archives, A Collective Documents about the Republic of China, Volume 3, Culture (Jiangsu Phoenix House, 1999)

Spence, Jonathan D. , The Search for Modern China (W.W. Norton \& Company, 2013)

Staunton, George Thomas, Ta Tsing Leu Lee: Being the Fundamental Laws, and a Selection from the Supplementary Statutes, of the Penal Code of China (Cambridge University Press,

2012)

Toman, Jiri , 'The Hague Convention-A Decisive Step Taken by the International Community' (2005 57(4) Museum International 7

Vattel, Emer de, Bela Kapossy and Richard Whatmore, The law of Nations (Liberty Fund, 2008)

Wang, Xi and Frederic Wakeman, China's Quest for Modernization: A Historical Perspective (Institute of East Asian Studies, University of California, Berkeley, 1997)

Wang, Yanping and John W. Head, Law Codes in Dynastic China: A Synopsis of Chinese Legal History in the Thirty Centuries from Zhou to Qing (Carolina Academic Press, 2005)

Woolsey, L. H. , 'The Forced Transfer of Property in Enemy Occupied Territories' (1943 37(2) The American Journal of International Law 282

Zhangsun, Wuji , Tang Lü Shu Yi (Taiwan shang wu yin shu guan, 1965)

Zhong, Hui , 'Can Chinese Individuals Request the Restitution of Chinese Cultural Relics in Japan?: A Revisit under International Law' (2017 10(1) Journal of East Asia \& International Law 179

Zhong, Hui , 'Legal Protection of Chinese Cultural Relics: A Justification for the Return' (2015 XX(1) Art Antiquity and Law 47

Zhu, Qingqi , Derk Bodde and Clarence Morris , Law in Imperial China: Exemplified by 190 Ch'ing Dynasty Cases (Harvard University Press, 1967)

\section{Customary International Law}

'Assessment of Customary International Law' (International Committee of the Red Cross <https://ihl-databases.icrc.org/customary-ihl/eng/docs/v1_rul_in_asofcuin> Akehurst, Michael , 'Custom as a Source of International Law' (1975 47(1) British Yearbook of International Law 1

Akehurst, Michael , A Modern Introduction to International Law (Allen and Unwin, 1987)

Brownlie, Ian and James Crawford, Brownlie's Principles of Public International Law (Oxford University Press, 2012)

Byers, Michael, Custom, Power and the Power of Rules: International Relations and Customary International Law (Cambridge University Press, 1999)

Cassese, Antonio , International Criminal Law (Oxford University Press, 2008)

Charlesworth, Hilary C. M. , 'Customary international law and the Nicaragua case' (1991 11 Australian Yearbook of International Law 1 
Charney, J. I. , 'The Persistent Objector Rule and the Development of Customary International Law' (1985 56(1) British Yearbook of International Law 1

Colson, David A. , 'How Persistent Must the Persistent Objector Be?' (1986 61(3)

Washington Law Review 957

D'Amato, Anthony A. , The Concept of Custom in International Law (Cornell University Press, 1971)

Doimi di Delupis, Ingrid , The Concept of International Law (Norstedts, 1987)

Dunbar, N. C. H. , 'The Myth of Customary International Law' (1978 8 Australian Year Book of International Law 1

Friedmann, W. , The Changing Structure of International Law (Stevens, 1964)

Goldsmith, Jack L. and Eric A. Posner, The Limits of International Law (Oxford University

Press, 2005)

Heinze, Eric and Malgosia Fitzmaurice, Landmark Cases in Public International Law (Kluwer Law International, 1998)

Henckaerts, Jean-Marie , 'Study on Customary International Humanitarian Law: A

Contribution to the Understanding and Respect for the Rule of Law in Armed Conflict' (2005

87(857) International Review of the Red Cross 175

Henckaerts, Jean-Marie and Louise Doswald-Beck , Customary International Humanitarian

Law, Volume 1 (Cambridge University Press, 2005)

ILA, 'Formation of Customary (General) International Law' (International Law Association, 2000) <www.ila-hq.org/en/committees/index.cfm/cid/30>

Jia, Bing Bing , 'The Relations between Treaties and Custom' (2010 9(1) Chinese Journal of International Law 81

John Austin, Wilfrid E. Rumble , Austin: The Province of Jurisprudence Determined

(Cambridge University Press, 1995)

Kammerhofer, Jorg , 'Uncertainty in the Formal Sources of International Law: Customary International Law and Some of Its Problems' (2004 15(3) European Journal of International Law 523

Kelly, J. Patrick , 'The Twilight of Customary International Law' (2000 40(2) Virginia Journal of International Law 449

Lepard, Brian D. , Customary International Law: A New Theory with Practical Applications (Cambridge University Press, 2010)

Malanczuk, Peter and Michael Barton Akehurst, Akehurst's Modern Introduction to International Law (Routledge, 1997)

Meijers, H. , 'How is International Law Made?-The Stages of Growth of International Law and the Use of its Customary Rules' (1978 9 Netherlands Yearbook of International Law 3 Schlütter, Birgit, Developments in Customary International Law: Theory and the Practice of the International Court of Justice and the International Ad Hoc Criminal Tribunals for Rwanda and Yugoslavia (Martinus Nijhoff Publishers, 2010)

Schwarzenberger, Georg, International Law: As Applied by International Courts and Tribunals (Stevens, 1957)

Shaw, Malcolm N. , International Law (Cambridge University Press, 2014)

Stein, Ted L. , 'The Approach of the Different Drummer: The Principle of the Persistent Objector in International Law' (1985 26(2) Harvard International Law Journal 457

Weller, Matthias , 'Immunity For Artworks on Loan? A Review of International Customary Law and Municipal Anti-Seizure Statutes in Light of the Liechtenstein Litigation' (2005 38(4)

Vanderbilt Journal of Transnational Law 997

Wolfke, Karol , Custom in Present International Law (Martinus Nijhoff Publishers, 1993) Woudenberg, Nout van, State Immunity and Cultural Objects on Loan (Martinus Nijhoff Publishers, 2012) 


\section{Return of Cultural Heritage Looted during Armed Conflicts}

'The 1954 Hague Convention' US Committee of the Blue Shield <http://uscbs.org/1954hague-convention.html>

'Act implementing the Convention of 14 May 1954 for the Protection of Cultural Property in the Event of Armed Conflict' <www.kulturgutschutz-

deutschland.de/SharedDocs/ExterneLinks/EN/Gesetze_en/KultgSchKonvAG_en.pdf;jsession id=40024BC88161857C417ADAB4679C55D2.1_cid350̄?_blob=publicationFile>

'Act of 8 March 2007 containing rules on the taking into custody of cultural property from an occupied territory during an armed conflict and for the initiation of proceedings for the return of such property'

$<$ www.unesco.org/culture/natlaws/media/pdf/netherlands/netherlands_actmarch2007_engtof. pdf>

'Act of 8 March 2007 containing rules on the taking into custody of cultural property from an occupied territory during an armed conflict and for the initiation of proceedings for the return of such property (Cultural Property Originating from Occupied Territory (Return) Act)'

$<w w w . e u i . e u / P r o j e c t s / I n t e r n a t i o n a l$ ArtHeritageLaw/Documents/NationalLegislation/Netherlan ds/actof2007coveringoccupiedterritory.pdf>

'Britain Should Ratify Convention to Protect Cultural Objects in Time of War', Telegraph July 212014 <www.telegraph.co.uk/comment/letters/10979564/Britain-should-ratify-conventionto-protect-cultural-objects-in-time-of-war.html>

'British Government Announces Plans to Ratify the 1954 Hague Convention' (UK National Committee of the Blue Shield, June 22 2015) <http://ukblueshield.org.uk/british-governmentannounces-plans-to-ratify-the-1954-hague-convention/>

'British Museum 'Guarding' Object Looted from Syria', BBC June 52015

<www.bbc.co.uk/news/entertainment-arts-33020199>

'Council Regulation (EU) No 1332/2013 of 13 December 2013 Amending Regulation (EU) No 36/2012 Concerning Restrictive Measures in View of the Situation in Syria' <http://eurlex.europa.eu/legal-content/EN/TXT/HTML/?uri=CELEX:32012R0036\%20\&from=EN> 'Draft Cultural Property (Armed Conflicts) Bill' (January 2008)

<www.gov.uk/government/uploads/system/uploads/attachment_data/file/243113/7298.pdf>

'Explanatory Memorandum'

$<$ www.unesco.org/culture/natlaws/media/pdf/netherlands/netherlands_memo_returnoccupied territory_engtof.pdf>

'Federal Law on the Protection of Cultural Objects in the Event of Armed Conflict, Disaster and Emergency Situations'

$<$ www.unesco.org/culture/natlaws/media/pdf/switzerland/suisse_fedactprotcltprop_entof> 'Government Tackles International Cultural Destruction' (Historic England, June 22 2015)

$<$ www.historicengland.org.uk/news-and-features/news/the-hague-ratify>

'The Hague Convention and the Hague Protocol (Message from the President of the United States)' <www.gpo.gov/fdsys/pkg/CDOC-106tdoc1/html/CDOC-106tdoc1.htm>

'Iraq (United Nations Sanctions) Order, Statutory Instrument 2003 No. 1519' (June 22 2003) $<$ www.unesco.org/culture/natlaws/media/pdf/gb/gb_iraqunitednationssanctions2003_engorof. pdf>

'Joint Communique of the Government of Japan and the Government of the People's Republic of China' (1972 Ministry of Foreign Affairs of Japan <www.mofa.go.jp/region/asiapaci/china/joint72.html>

'New Scheme to Protect Cultural Sites from Destruction' (UK Government, October 282015 ) $<$ www.gov.uk/government/news/new-scheme-to-protect-cultural-sites-from-destruction>

'Other Cases of Return or Restitution of Cultural Obejcts' (UNESCO

$<$ www.unesco.org/new/en/culture/themes/illicit-trafficking-of-cultural-property/other-cases-ofreturn-or-restitution-of-cultural-objects/>

'Practice Relating to Rule 150. Reparation' ICRC <www.icrc.org/customary-

ihl/eng/docs/v2_cha_chapter42_rule150_sectionb>

'President Signs Engel Bill to Stop Isis From Looting Antiquities', US Committee of the Blue

Shield May 92016 <http://uscbs.org/news/president-signs-engel-bill-stop-isis-looting-

antiquities/> 
'United Nations Security Council Resolution 2199'

<http://unesdoc.unesco.org/images/0023/002321/232164e.pdf>

'War Damage on Cultural Relics Commission under the Department of Education', China Cultural Relics August 222007 <www.xhgxt.com/html/View_9270.html>

Bassiouni, M. Cherif , 'Reflections on Criminal Jurisdiction in International Protection of Cultural Property' (1983 10(2) Syracuse Journal of International Law and Commerce 281

Bong, Shin Hae , 'Compensation for Victims of Wartime Atrocities: Recent Developments in Japan's Case Law' (2005 3(1) Journal of International Criminal Justice 187

Brodie, Neil and Colin Renfrew , 'Looting and the World's Archaeological Heritage: The Inadequate Response' (2005 34 Annual Review of Anthropology 343

Chechi, Alessandro, The Settlement of International Cultural Heritage Disputes (Oxford University Press, 2014)

Downey, William Gerald , 'Captured Enemy Property: Booty of War and Seized Enemy Property' (1950 44(3) The American Journal of International Law 488

Einhorn, Talia , 'Restitution of Archaeological Artifacts: The Arab-Israeli Aspects' (1996 5(1) International Journal of Cultural Property 133

Ferrari, Silvio and Andrea Benzo, Between Cultural Diversity and Common Heritage: Legal and Religious Perspectives on the Sacred Places of the Mediterranean (Ashgate, 2014)

Forrest, Craig , International Law and The Protection of Cultural Heritage (Routledge, 2010) Forsyth, Marion , 'Casualties of War: The Destruction of Iraq's Cultural Heritage as a Result of US Action During and After the 1991 Gulf War' (2004 XIV DePaul-LCA Journal of Art \& Entertainment Law 73

Francioni, Francesco , 'The Evolving International Legal Framework for the Protection of Cultural Heritage' in Silvia Borelli and Federico Lenzerini (eds), Cultural Heritage, Cultural Rights, Cultural Diversity (Brill, 2012) 3

Freeman, Alwyn V. , 'General Note on the Law of War Booty' (1946 40(4) The American Journal of International Law 795

Gerstenblith, Patty , '2010 Cultural Heritage Legal Summary' (2011 36(3) Journal of Field Archaeology 257

Gerstenblith, Patty , 'Increasing Effectiveness of The Legal Regime for the Protection of the International Archaeological Heritage' in James A.R. Nafziger and Ann Nicgorski (eds), Cultural Heritage Issues (Martinus Nijhoff Publishers, 2009) 305

He, Yinan , 'The Bitter Legacies of the 1972 Sino-Japanese Normalization Talks' (China and The World Program, May 29 2017) <https://cwp.princeton.edu/news/bitter-legacies-1972sino-japanese-normalization-talks-article-cwp-alumni-yinan-he>

Henckaerts, Jean-Marie and Louise Doswald-Beck, Customary International Humanitarian Law, Volume 1 (Cambridge University Press, 2005)

Henckaerts, Jean-Marie and Louise Doswald-Beck, Customary International Humanitarian Law, Volume 2 (Cambridge University Press, 2005)

Hladik, Jan, 'The Review Process of the 1954 Hague Convention for the Protection of Cultural Property in the Event of Armed Conflict and its Impact on International Humanitarian Law' (1998 1 Yearbook of International Humanitarian Law 313

Jakubowski, Andrzej , State Succession in Cultural Property (Oxford University Press, 2015) Jote, Kifle , International Legal Protection of Cultural Heritage (Juristforlaget, 1994)

Kastenberg, Joshua E. , 'The Legal Regime for Protecting Cultural Property During Armed Conflict' (1997 42 Air Force Law Review 277

Kowalski, Wojciech , Art Treasures and War: A Study on the Restitution of Looted Cultural Property Pursuant to Public International Law (Art, Antiquity and Law, 1998)

Kozai, Shigeru and Toshiyuki Kono , 'Japan' in James A.R. Nafziger and Robert Paterson (eds), Handbook on the Law of Cultural Heritage and International Trade (2014 257

Matyk, Stephan , 'The Restitution of Cultural Objects and the Question of Giving Direct Effect to the Protocol to the Hague Convention for the Protection of Cultural Property in the Event of Armed Conflict 1954' (2000 9(2) International Journal of Cultural Property 341

Meyer, David A. , 'The 1954 Hague Cultural Property Convention and its emergence into customary international law' (1993 11(2) Boston University International Law Journal 349 
Nafziger, James A.R. and Robert Paterson, 'Cultural Heritage Law' in James A.R. Nafziger and Robert Paterson (eds), Handbook on the Law of Cultural Heritage and International Trade (Edward Elgar Publishing, 2014) 1

Neuhaus, Nina M. , 'Switzerland Limits Trade in Syrian Cultural Property' (Institute of Art and Law Blog, January 14 2015) <www.ial.uk.com/news/switzerland-limits-trade-in-syriancultural-property/>

Nicholas, Lynn H. , The Rape of Europa: The Fate of Europe's Treasures in the Third Reich and the Second World War (Vintage, 1995)

Paterson, Robert , 'Resolving Material Culture Disputes: Human Rights, Property Rights, and Crimes against Humanity' in James A.R. Nafziger and Ann Nicgorski (eds), Cultural Heritage Issues (Martinus Nijhoff Publishers, 2009) 371

Paul Martin , Ed Vulliamy and Gaby Hinsliff , 'US Army Was Told to Protect Looted Museum', The Guardian April 212003

<www.theguardian.com/world/2003/apr/20/internationaleducationnews.iraq>

Peters, Robert , 'Remedying Historical Injustice: Ethical and Historical Considerations in

Returning Cultural Materials' in Silvia Borelli and Federico Lenzerini (eds), Cultural Heritage,

Cultural Rights, Cultural Diversity (Martinus Nijhoff Publishers, 2012) 141

Prott, Lyndel , 'The History and Development of Processes for the Recovery of Cultural

Heritage' in Lyndel Prott (ed), Witnesses to History (UNESCO, 2008) 2

Redmond-Cooper, Ruth, 'Call for UK Government to ratify Hague Convention' (Institute of

Art and Law Blog, 2015) <www.ial.uk.com/news/call-for-uk-government-to-ratify-hague-

convention/>

Renold, Marc-André , 'Cross-Border Restitution Claims of Art Looted in Armed Conflicts and Wars and Alternatives to Court Litigations' (European Parliament Think Tank

<www.europarl.europa.eu/RegData/etudes/STUD/2016/556947/IPOL_STU(2016)556947_E N.pdf>

Roberts, Adam , Documents on the Laws of War (Oxford University Press, 2000)

Roodt, Christa, Private International Law, Art and Cultural Heritage (Edward Elgar

Publishing, 2015)

Sandholtz, Wayne , 'The Iraqi National Museum and International Law: A Duty to Protect' (2005 44(1) Columbia Journal Transnational Law 185

Sandholtz, Wayne , 'Plunder, Restitution, and International Law' (2010 17(2) International Journal of Cultural Property 147

Sandholtz, Wayne, Prohibiting Plunder: How Norms Change (Oxford University Press, 2007) Scott, Carol , 'UK to Adopt Hague Convention to Protect Artefacts in War Zones' (ICOM, June 22 2015) <http://uk.icom.museum/uk-to-adopt-hague-convention-to-protect-artefacts-inwar-zones/>

Scott, Geoffrey R. , 'Spoliation, Cultural property, and Japan' (2008 29(4) University of

Pennsylvania Journal of International Law 803

Second Historical Archives of China, China, A Collective Documents about the Republic of

China, Volume 5, Issue 3, Culture (Jiangsu Phoenix House, 1999)

Shelton, Dinah , 'The World of Atonement: Reparations for Historical Injustices' (2003 50(3)

Netherlands International Law Review 289

Toman, Jiri , 'The Hague Convention-A Decisive Step Taken by the International

Community' (2005 57(4) Museum International 7

Toman, Jiri , The Protection of Cultural Property In the Event of Armed Conflict: Commentary on the 1954 Hague Convention and on Other Instruments of International Law Concerning Such Protection (Dartmouth, 1996)

Vigneron, Sophie, 'Protecting Cultural Objects: Enforcing the Illicit Export of Foreign Cultural Objects' in Valentina Vadi and Hildegard Schneider (eds), Art, Cultural Heritage and the Market: Ethical and Legal Issues (Springer, 2014) 117

Vrdoljak, Ana Filipa , International Law, Museums and The Return of Cultural Objects (Cambridge University Press, 2006)

Xiaodong, Li , An Analysis on the Legal Documents regarding Cultural Relics in Republic of China (Cultural Relics Press, 2013) 


\section{Return of Cultural Heritage Stolen and Illegally Exported in Peacetime}

'Bilateral Agreements' <http://eca.state.gov/cultural-heritage-center/cultural-propertyprotection/bilateral-agreements>

'Choice of Law in Litigation to Recover National Cultural Property: Efforts at Harmonization in Private International Law' (1990 31 Virginia Journal of International Law 1

'Cultural Property Protection' (US Bureau of Educational and Cultural Affairs

$<$ https://eca.state.gov/cultural-heritage-center/cultural-property-protection/process-and-

purpose/background>

'Directive 2014/60/EU of the European Parliament and of the Council of 15 May 2014 on the return of cultural objects unlawfully removed from the territory of a Member State and amending Regulation (EU) No 1024/2012 (Recast).' <http://eur-lex.europa.eu/legalcontent/EN/TXT/PDF/?uri=CELEX:32014L0060\&from=EN>

'Exlanatory Notes on Dealing In Cultural Objects (Offences) Bill', UK Parliament <www.publications.parliament.uk/pa/ld200203/ldbills/090/en/03090x--.htm>

'Fourth Report on the Application of Council Directive 93/7/EEC on the Return of Cultural Objects Unlawfully Removed From the Territory of a Member State', European Commission, $2013<$ http://eur-lex.europa.eu/legal-

content/EN/TXT/PDF/?uri=CELEX:52013DC0310\&from=EN>

'Guidance on the Dealing in Cultural Objects (Offences) Act 2003'

<http://old.culture.gov.uk/images/publications/Dealincultural.pdf>

'The International Sale of Works of Art from the Angle of the Protection of the Cultural Heritage', Institute of International Law <www.idi-

iil.org/idiE/resolutionsE/1991_bal_04_en.PDF>

'Key Aspects of the New Act on the Protection of Cultural Property in Germany', Germany's Federal Government Commissioner for Culture and the Media, September 2016

$<$ www.congreso.es/docu/docum/ddocum/dosieres/sleg/legislatura_12/spl_3/pdfs/22.pdf>

'Memorandum of Understanding (MOU), to Protect Categories of Archaeological Material from the Paleolithic Period through the Tang Dynasty, and Monumental Sculpture and Wall art at least 250 Years Old', Bureau of Educational and Cultural Affairs

$<$ http://eca.state.gov/cultural-heritage-center/international-cultural-property-

protection/bilateral-agreements/china>

'The New Act on the Protection of Cultural Property in Germany: implementing the UNESCO 1970 Convention and new EU law'

$<$ www.unesco.org/fileadmin/MULTIMEDIA/HQ/CLT/pdf/presentation_UNESCO_Germany.pdf $>$

'The Nigerian Bronzes Case' in Lyndel Prott (ed), Witnesses to history. Documents and Writings on the Return of Cultural Objects (UNESCO, 2009) 33

'Recent Examples of Successful Operations of Cultural Property Restitutions in the World' UNESCO <www.unesco.org/new/en/culture/themes/restitution-of-cultural-

property/successful-restitutions-in-the-world/>

'Return of Illegally Exported Cultural Objects: Simpler Rules', European Parliament January

$212014<$ www.europarl.europa.eu/news/en/news-

room/content/20140120IPR33131/html/Return-of-illegally-exported-cultural-objects-simplerrules>

'Seventh Report of the Select Committee on Culture, Media and Sport' <www.parliament.thestationery-office.co.uk/pa/cm199900/cmselect/cmcumeds/371/37106.htm>

'US Senate Report, 97-564 Implementing Legislation for the Convention on the Means of Prohibiting and Preventing the Illicit Import, Export and Transfer of Ownership of Cultural Property' <https://eca.state.gov/files/bureau/97-564.pdf>

Bibas, Stephanos , 'The Case Against Statutes of Limitations for Stolen Art' (1996 5(1)

International Journal of Cultural Property 73

Blake, Janet, International Cultural Heritage Law (Oxford University Press, 2015)

Blake, Janet, 'Turkey' in James A.R. Nafziger and Robert Paterson (eds), Handbook on the Law of Cultural Heritage and International Trade (Edward Elgar Publishing, 2014)

Bolano, Maritza F. , 'International Art Theft Disputes: Harmonizing Common Law Principles with Article 7 of the UNESCO Convention' (1991 15(1) Fordham International Law Journal 
Borodkin, Lisa , 'The Economics of Antiquities Looting and a Proposed Legal Alternative' (1995 95(2) Columbia Law Review 377

Bouchenaki, M. , 'Return and Restitution of Cultural Property in the Wake of the 1970 Convention' (2009 61(1-2) Museum International 139

Briggs, Aaron Kyle , 'Consequences of the Met-Italy Accord for the International Restitution of Cultural Property' (2007 7(2) Chicago Journal of International Law 623

Burke, Karen Theresa , 'International Transfers of Stolen Cultural Property: Should Thieves Continue to Benefit From Domestic Laws Favoring Bona Fide Purchasers?' (1990 13(2) Loyola of Los Angeles International and Comparative Law Journal 427

Cassella, Stefan D. , 'Using the Forfeiture Laws to Protect Archaeological Resources' (2006 41 Idaho Law Review 129

Chamberlain, Kevin and Kristin Hausler, 'United Kingdom' in James A.R. Nafziger and Robert Paterson (eds), Handbook on the Law of Cultural Heritage and International Trade (Edward Elgar Publishing, 2014) 460

Chechi, Alessandro, The Settlement of International Cultural Heritage Disputes (Oxford University Press, 2014)

Church, Judith , 'Evolving US Case Law on Cultural Property' (1993 2(1) International Journal of Cultural Property 47

Day, Michael , 'Italy Celebrates as 5,000 Plundered Artefacts Worth €50m are Returned following 14-year Inquiry', Independent January 222015

$<w w w . i n d e p e n d e n t . c o . u k / n e w s / s c i e n c e / a r c h a e o l o g y / n e w s / i t a l y-c e l e b r a t e s-a s-5000-$ plundered-artefacts-worth-50m-are-returned-following-14year-inquiry-9996427.html> Drum, Sydney M. , 'Deweerth v Baldinger: Making New York a haven for stolen art?' (1989 64(4) New York University Law Review 909

Eisen, Leah E. , 'Commentary, The Missing Piece: A Discussion of Theft, Statutes of Limitations, and Title Disputes in the Art World' (1991 81(4) Journal of Criminal Law and Criminology 1067

Fincham, Derek, 'How Adopting the lex originis rule can Impede the Flow of Illicit Cultural Property' (2008 32(1) The Columbia Journal of Law \& the Arts 111

Fincham, Derek , 'Iran v Barakat: Iran Wins Barakat Appeal' in Lyndel Prott (ed), Witnesses to History: A Compendium of Documents 2009 and Writings on the Return of Cultural Objects (United Nations Educational, Scientific and Cultural Organization, 2009) 388

Fiorentini, Francesca , 'A Legal Pluralist Approach to International Trade in Cultural Objects' in James A.R. Nafziger and Robert Paterson (eds), Handbook on the Law of Cultural Heritage and International Trade (Edward Elgar Pub, 2014) 589

Frey, Laurie, 'Bakalar v Vavra and the Art of Conflicts Analysis in New York: Framing a Choice of Law Approach for Moveable Property' (2012 112(5) Columbia Law Review 1055 Gerstenblith, Patty , 'Enforcement by Domestic Courts: Criminal Law and Forfeiture in the Recovery of Cultural Objects' in Francesco Francioni and James Gordley (eds), Enforcing International Cultural Heritage Law (Oxford University Press, 2013) 150

Gerstenblith, Patty , 'For Better and For Worse: Evolving United States Policy on Cultural Property Litigation and Restitution' (2015 22(2-3) International Journal of Cultural Property 357

Gerstenblith, Patty , 'Implementation of the 1970 UNESCO Convention by the United States and Other Market Nations' <www.law.upenn.edu/live/files/6423-gerstenblith-patty-2017implementation-of-the-1970>

Gerstenblith, Patty , 'Increasing Effectiveness Of The Legal Regime For The Protection Of The International Archaeological Heritage' in James A.R. Nafziger and Ann Nicgorski (eds), Cultural Heritage Issues (Martinus Nijhoff Publishers, 2009) 305

Gerstenblith, Patty , 'Schultz and Barakat: Universal Recognition of National Ownership of Antiquities' (2009 (1) Art Antiquity and Law 21

Gordley, James , 'The Enforcement of Foreign Law: Reclaiming One Nation's Cultural Heritage in Another Nation's Courts' in Francesco Francioni and James Gordley (eds), Enforcing International Cultural Heritage Law (Oxford University Press, 2013) 110 Green, Simon Mackenzie and Penny , 'Introduction: A Context for the Engagement of Criminology and Archaeology' in Simon Mackenzie and Penny Green (ed), Criminology and 
Archaeology: Studies in Looted Antiquities (Hart Publishing, 2009) 1

Hayworth, Andrea E. , 'Stolen Artwork: Deciding Ownership Is No Pretty Picture' (1993 43(2)

Duke Law Journal 337

Hoffman, Matthew R. , 'Cultural Pragmatism: A New Approach to the International Movement of Antiquities' (2010 95(2) lowa Law Review 665

Jower, Kevin , 'Comment: International and National Legal Efforts to Protect Cultural

Property: The 1970 UNESCO Convention, the United States, and Mexico' (2003 38 Texas International Law Journal 145

Kaye, Lawrence M. , 'Art Wars: The Repatriation Battle' (1998 31 New York University Journal of International Law and Politics 79

Kaye, Lawrence M. , 'Recovery of Stolen Cultural Property: A Practitioner's View-War Stories and Morality Tales' (1998 (5) Villanova Sports \& Entertainment Law Journal 5 Kaye, Lawrence and Carla Main , 'The Saga of the Lydian Hoard Antiquities: From Usak to New York and Back and Some Related Observations on the Law of Cultural Repatriation' in Kathryn Tubb (ed), Antiquities Trade or Betrayed: Legal, Ethical \& Conservation Issues (Archetype, 1995)

Knapp, Krystal , 'Princeton University Returns Art to Italy', Planet Princeton January 262012 $<$ http://planetprinceton.com/2012/01/26/princeton-university-returns-art-to-italy/>

Kozai, Shigeru and Toshiyuki Kono , 'Japan' in James A.R. Nafziger and Robert Paterson (eds), Handbook on the Law of Cultural Heritage and International Trade (2014 257 Laird, Michèle , 'Closing in on the Archaeological Underworld', Swissinfo July 182012 $<$ www.swissinfo.ch/eng/free-port-problem_closing-in-on-the-archaeologicalunderworld/33088854>

Litt, Steven , 'Cleveland Museum of Art Strikes Deal With Italy to Return 14 Ancient Artworks', Cleveland November 192008

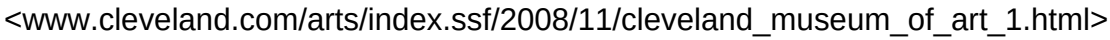
Logan, Mia J. , 'Limiting Access to Art in Hopes of Decreased Cultural Property Destruction: An Assessment of the United States and China's Memorandum of Understanding for 2014' (2014 1 Art Antiquity and Law 1

Lufkin, Martha , 'Egyptian Antiquities Dealer Found Guilty', Forbes February 202002 <www.forbes.com/2002/02/20/0220hot.html>

Mackenzie, Simon, Going, Going, Gone: Regulating the Market in Illicit Antiquities (Institute of Art and Law, 2005)

Mackenzie, Simon and Penny Green , 'Criminalising the Market in Illicit Antiquities: an Evaluation of the Dealing in Cultural Objects (Offences) Act 2003 in England and Wales' in Simon Mackenzie and Penny Green (eds), Criminology and Archaeology: Studies in Looted Antiquities (Hart Publishing, 2009) 145

Mackey, Larry A. , 'ARPA on Private Lands: The GE Mound Case' in Sherry Hutt , Marion Forsyth and David Tarler (eds), Presenting Archaeology in Court: Legal Strategies for Protecting Cultural Resources (AltaMira Press, 2006) 47

Marous, Sarah and J. Michael Marous, 'ARPA in the International Context: Protecting the Articles of Faith' in Sherry Hutt , Marion Forsyth and David Tarler (eds), Presenting Archaeology in Court: Legal Strategies for Protecting Cultural Resources (AltaMira Press, 2006) 39

Mellor, James , 'Egyptian Treasures Smuggler is Jailed', Independent June 181997 $<w w w . i n d e p e n d e n t . c o . u k / n e w s / e g y p t i a n-t r e a s u r e s-s m u g g l e r-i s-j a i l e d-1256685 . h t m l>$ Morrow, Jessica Eve , 'The National Stolen Property Act and the Return of Stolen Cultural Property to Its Rightful Foreign Owners' (2007 30(1) Boston College International and Comparative Law Review 249

Nafziger, James A.R. and Robert Kirkwood Paterson, 'Cultural Heritage Law' in James A.R. Nafziger and Robert Kirkwood Paterson (eds), Handbook on the Law of Cultural Heritage and International Trade (Edward Elgar Publishing, 2014)

Neuhaus, Nina M. , 'Switzerland Returns 32 Antiquities to Egypt', Institute of Art and Law Blog, June 102015 <www.ial.uk.com/news/switzerland-returns-32-antiquities-to-egypt/> Neuhaus, Nina M. , 'Switzerland Returns Illegally Imported Terracotta Statue To China',

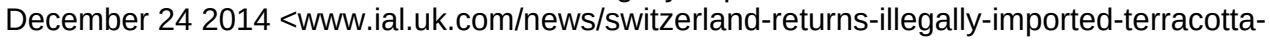
statue-to-china/> 
O'Hagan, John and Clare McAndrew , 'Export Restrictions, Tax Incentives and the National Artistic Patrimony' (2000 10(37) Cultural Trends 41

O'Keefe, Patrick , 'Using UNIDROIT to Avoid Cultural Heritage Disputes: Limitation Periods' (2009) 14 Willamette Journal of International Law and Dispute Resolution 227

Olivier, Monique , 'The UNIDROIT Convention: Attempting to Regulate the International Trade and Traffic of Cultural Property' (1996 26(1-3) Golden Gate University Law Review 627

Ozel, Sibel , 'Case note. The Basel Decisions: Recognition of the Blanket Legislation Vesting State Ownership Over the Cultural Property Found Within the Country of Origin' (2000 9(2) International Journal of Cultural Property 315

Ozel, Sibel , 'Under the Turkish Blanket Legislation: The Recovery of Cultural Property Removed from Turkey' (2010 38(2) International Journal of Legal Information 177

Palmer, Norman , 'Statutory, Forensic and Ethical Initiatives in the Recovery of Stolen Art and Antiquities' in Norman Palmer (ed), The Recovery of Stolen Art: A Collection of Essays (Kluwer Law International, 1998)

Park, Sue J. , 'The Cultural Property Regime in Italy: An Industrialized Source Nation's Difficulties in Retaining and Recovering its Antiquities' (2002 23(4) University of Pennsylvania Journal of International Economic Law 931

Phalnikar, Sonia , 'Germany Acquired Nefertiti Illegally, Egyptian Official Says', DW

December 222009 <www.dw.com/en/germany-acquired-nefertiti-illegally-egyptian-officialsays/a-5046115>

Povoledo, Elisabetta , 'Boston Museum Returns 13 Ancient Works to Italy', New York Times September 292006 <www.nytimes.com/2006/09/29/arts/design/29mfa.html?_r=0>

Povoledo, Elisabetta , 'Italy and Getty Sign Pact on Artifacts', New York Times September 26 2007 <www.nytimes.com/2007/09/26/arts/design/26gett.html?_r=0\&pagewanted=print>

Povoledo, Elisabetta, 'Met to Sign Accord in Italy to Return Vase and Artifacts', New York Times February 212006

<www.nytimes.com/2006/02/21/arts/design/21anti.html?pagewanted=print>

Prott, Lyndel , 'Problems of Private International Law for the Protection of the Cultural Heirtage' in Hague Academy of International Law (ed), Collected Courses of the Hague Academy of International Law (Nijhoff, 1989) 215

Prott, Lyndel , 'UNESCO and UNIDROIT: a Partnership against Trafficking in Cultural Objects" (1996 1 Uniform Law Review 59

Renold, Marc-André , 'An Important Swiss Decision Relating to the International Transfer of Cultural Goods: The Swiss Supreme Court's Decision on the Giant Antique Mogul Gold Coins' (2006 13(3) International Journal of Cultural Property 361

Renold, Marc-André and Beat Schönenberger , 'Switzerland' in James A.R. Nafziger and Robert Paterson (eds), Handbook on the Law of Cultural Heritage and International Trade (Edward Elgar Publishing, 2014) 408

Roodt, Christa, Private international law, Art and Cultural heritage (Edward Elgar Publishing, 2015)

Schechter, Rhonda, 'Preventing Pillage and Promoting Politics: The Dual Goals of the 2009 US-China Bilateral Agreement to Restrict Imports of Chinese Cultural Property' (2009 4 Art Antiquity and Law 317

Siehr, Kurt , 'Germany' in James A.R. Nafziger and Robert Paterson (eds), Handbook on the Law of Cultural Heritage and International Trade (Edward Elgar Publishing, 2014) 160

Siehr, Kurt , 'The Protection of Cultural Heritage and International Commerce' (1997 6(2) International Journal of Cultural Property 304

Slayman, A. , 'Recent Cases of Repatriation of Antiquities to Italy from the United States' (1998 7(2) International Journal of Cultural Property 456

Spiegler, Howard N. , 'The UNESCO Convention's Role in American Cultural Property Law: The Journey to US v Frederick Schultz' in Museum International: Protection and Restitution (2005 103

Stephen E , Weil , 'The American Legal Response to the Problem of Holocaust Art' (1999 IV(4) Art Antiquity and Law 285

Symeonides, Symeon C. , 'A Choice-of-Law Rule for Conflicts Involving Stolen Cultural Property' (2005 38(4) Vanderbilt Journal of Transnational Law 1177 
Ulph, Janet , 'UK Customs seizure of looted Libyan statue', Institute of Art and Law Blog, October 222015 <www.ial.uk.com/news/uk-customs-seizure-of-looted-libyan-statue/> Ulph, Janet and Ian Smith, The Illicit Trade in Art and Antiquities: International Recovery and Criminal and Civil Liability (Hart Publishing, 2012)

Vigneron, Sophie, 'Protecting Cultural Objects: Enforcing the Illicit Export of Foreign Cultural Objects' in Valentina Vadi and Hildegard Schneider (eds), Art, Cultural Heritage and the Market: Ethical and Legal Issues (Springer, 2014) 117

Wantuch-Thole, Mara, Cultural Property in Cross-Border Litigation: Turning Rights into Claims (De Gruyter, 2014)

Weber, Marc , 'New Swiss Law on Cultural Property' (2006 13(1) International Journal of Cultural Property 99

Yasaitis, Kelly Elizabeth, 'National Ownership Laws as Cultural Property Protection Policy: The Emerging Trend in United States v Schultz' (2005 12(1) International Journal of Cultural Property 95

\section{Evolving Social and Ethical Norms}

'Blood Antiquities: After Lengthy Fight, Sotheby's Agrees to Return Looted Khmer Statue', Chasing Aphrodite, December 162013 <http://chasingaphrodite.com/2013/12/16/bloodantiquities-after-lengthy-fight-sothebys-agrees-to-return-looted-khmer-statue/> 'British Museum Policy on Acquisitions' (2007 <www.britishmuseum.org/pdf/Acquisitions.pdf> 'Case Review: US v Mask of Ka-Nefer-Nefer (8th Cir.)', Center for Art Law $<$ https://itsartlaw.com/tag/ka-nefer-nefer/>

'Chinese Mummy Buddha: Dutch Collector's Conditions for Repatriation Raise Questioning over His Sincerity', Xinhua Net December 102015 <http://news.xinhuanet.com/english/201512/10/c_134901207.htm>

'Christie's Celebrates Return of 10th Century Statues to Cambodia at Official Ceremony in Phnom Penh' <www.christies.com/about-us/press-archive/details/?pressreleaseid=7298> 'Code of Ethics for Museums', Museums Association $<$ www.museumsassociation.org/download?id=1155827>

'Dancing Shiva Statue_-India and National Gallery of Australia', Art Law Center, University of Geneva <https://plone.unige.ch/art-adr/cases-affaires/dancing-shiva-statue-2013-india-andnational-gallery-of-australia>

'Dutch Court to Hold First Hearing for Buddha Statue Dispute in July', People.cn February 3 2017 <http://en.people.cn/n3/2017/0203/c90000-9173553.html>

'Introduction to the Revisions to the 2008 Guidelines on the Acquisition of Archaeological Material and Ancient Art'

<https://aamd.org/sites/default/files/document/AAMD\%20Guidelines\%202013.pdf>

'Khmer Statue-Cambodia and Sotheby's and the United States', Art-Law Centre, University of Geneva <https://plone.unige.ch/art-adr/cases-affaires/khmer-statue-2013-cambodia-andsotheby2019s-and-the-united-states>

'Machu Picchu Collection-Peru and Yale University', Art Law Center, University of Geneva $<$ https://plone.unige.ch/art-adr/cases-affaires/machu-picchu-collection-2013-peru-and-yaleuniversity>

'Memorandum Submitted by the Museums Association', UK Government

<www.publications.parliament.uk/pa/cm199900/cmselect/cmcumeds/371/0032305.htm> 'Request for Return of the Shiva Nataraja Idol', Australian Attorney-General's Department March 262014

<https://nga.gov.au/COLLECTIONS/Asia/GALLERY.cfm?DISPLAYGAL=ASIAPROV_kapoor $>$

'Statement from Yale University Regarding Machu Picchu Archaeological Materials', Yale News November 212011 <http://news.yale.edu/2010/11/21/statement-yale-universityregarding-machu-picchu-archaeological-materials> 
Amineddoleh, Leila , 'The Role of Museums in Sustaining the Illicit Trade in Culutral Property' 25 Cardozo Arts \& Entertainment Law Journal 837

Blake, Janet, International Cultural Heritage Law (Oxford University Press, 2015)

Blumenthal, Ralph and Tom Mashberg , 'The Curse of the Outcast Artifact', The New York Times July 122012 <www.nytimes.com/2012/07/15/arts/design/antiquity-market-grappleswith-stricter-guidelines-for-gifts.html?_r=0>

Brodie, Neil , 'An Archaeologist's View of the Trade in Unprovenanced Antiquities' in Barbara T. Hoffman (ed), Art and Cultural Heritage: Law, Policy and Practice (Cambridge University Press, 2009) 52

Brodie, Neil et al, Trade in Illicit Antiquities: The Destruction of the World's Archaeological Heritage (McDonald Institute for Archaeological Research, 2001)

Brodie, Neil and Colin Renfrew , 'Looting and the World's Archaeological Heritage: The Inadequate Response' (2005 34 Annual Review of Anthropology 343

Chechi, Alessandro, 'Multi-Level Cooperation to Safeguard the Human Dimension of Cultural Heritage and to Secure the Return of Wrongfully Removed Cultural Objects' in Silvia Borelli and Federico Lenzerini (eds), Cultural Heritage, Cultural Rights, Cultural Diversity (Martinus Nijhoff Publishers, 2012) 347

Cornu, Marie and Marc-André Renold, 'New Developments in the Restitution of Cultural Property: Alternative Means of Dispute Resolution' (2010 17(1) International Journal of Cultural Property 1

Dobrzynski, Judith H. , 'Maybe The Ka-Nefer-Nefer Dispute Isn't Over', Blouin Artinfo June 26 2014 <http://blogs.artinfo.com/realcleararts/2014/06/26/maybe-the-ka-nefer-nefer-disputeisnt-over/>

Eakin, Hugh , 'Inca Show Pits Yale Against Peru', New York Times February 12006 $<$ www.nytimes.com/2006/02/01/arts/design/01mach.html>

Fincham, Derek , 'Social Norms and Illicit Cultural Heritage' in Francesco Francioni and James Gordley (eds), Enforcing International Cultural Heritage Law (Oxford University Press, 2013) 206

Fiorentini, Francesca , 'A Legal Pluralist Approach to International Trade in Cultural Objects' in James A.R. Nafziger and Robert Paterson (eds), Handbook on the Law of Cultural Heritage and International Trade (Edward Elgar Publishing, 2014) 589

Fitschen, Thomas , 'The Resolution on the Return and Restitution of Cultural Property to the Countries of Origin Adopted by the General Assembly on December 13, 2001' (2002 11(2) International Journal of Cultural Property 337

Frigo, Manlio , 'Ethical Rules and Codes of Honor Related to Museum Activities: A Complementary Support to the Private International Law Approach Concerning the Circulation of Cultural Property' (2009 16(1) International Journal of Cultural Property 49 Gay, Malcolm , 'For the St. Louis Art Museum, a Legal Victory Raises Ethical Questions', Atlantic May 302012 <www.theatlantic.com/national/archive/2012/05/for-the-st-louis-artmuseum-a-legal-victory-raises-ethical-questions/257839/>

Gerstenblith, Patty , 'The Meaning of 1970 for the Acquisition of Archaeological Objects' (2013 38(4) Journal of Field Archaeology 364

Glaister, Dan , 'Getty Museum Admits 350 More Treasures May Be Looted', Guardian June 192006 <www.theguardian.com/world/2006/jun/19/arts.usa>

Kennedy, Randy , 'Yale Officials Agree to Return Peruvian Artifacts', New York Times September 172009 <www.nytimes.com/2007/09/17/arts/design/17peru.html?_r=0> Listing, Rosemary , 'The Treasure Quest: Peru, Machu Picchu and the Yale Peruvian Expedition of 1911-1916 (Rosemary Listing)' (2011 16(1) Art Antiquity and Law 67 Lyme, Chloe, 'Battle for the Buddha: Angry Chinese Villagers sue Dutch Art Collector Who 'Refuses to Return Stolen Statue' Containing Mummified Remains of Meditating Monk', Daily Mail November 202015 < www.dailymail.co.uk/news/peoplesdaily/article-3327398/AngryChinese-villagers-sue-Dutch-art-collector-refuses-return-stolen-statue-containing-mummifiedremains-meditating-monk.html>

Mashberg, Tom and Ralph Blumenthal , 'Christie's to Return Cambodian Statue', New York Times May 62014 <www.nytimes.com/2014/05/07/arts/design/christies-to-return-cambodianstatue.html> 
Moustaira, Elina , Art Collections, Private and Public: A Comparative Legal Study (Springer, 2015)

Nafziger, James A.R. , 'Cultural Heritage Law: The International Regime' in James A.R. Nafziger and Tullio Scovazzi (eds), The Cultural Heritage of Mankind (Martinus Nijhoff/Brill, 2008) 145

Nafziger, James A.R. and Robert Paterson, 'Cultural Heritage Law' in James A.R. Nafziger and Robert Paterson (eds), Handbook on the Law of Cultural Heritage and International Trade (Edward Elgar Publishing, 2014) 1

Nason, James D. , 'Beyond Repatriation: Cultural Policy and Practice for the Twenty-First Century' in Professor Bruce Ziff (ed), Borrowed Power: Essays on Cultural Appropriation (Rutgers University Press, 1997) 290

Peters, Robert, 'Remedying Historical Injustice: Ethical and Historical Considerations in Returning Cultural Materials' in Silvia Borelli and Federico Lenzerini (eds), Cultural Heritage, Cultural Rights, Cultural Diversity (Martinus Nijhoff Publishers, 2012) 141

Prott, Lyndel, Witnesses to History: A Compendium of Documents and Writings on the Return of Cultural Objects (United Nations Educational, Scientific and Cultural Organization, 2009)

Roman, Kianti , 'Peru-Yale Center for the Study of Machu Picchu and Inca Culture opens', Yale News October 62011 <http://news.yale.edu/2011/10/06/peru-yale-center-study-machupicchu-and-inca-culture-opens $>$

Schechter, Rhonda , 'Preventing Pillage and Promoting Politics: The Dual Goals of the 2009 US-China Bilateral Agreement to Restrict Imports of Chinese Cultural Property' (2009 4 Art Antiquity and Law 317

Seiff, Abby , 'How Countries Are Successfully Using the Law to Get Looted Cultural Treasures Back', Art Journal July 12014

$<$ www.abajournal.com/magazine/article/how_countries_are_successfully_using_the_law_to_ get_looted_cultural_treasur>

Sims, Calvin , 'Japanese Agree A Stolen Statue Will Be Sent Back to China', New York Times April 182001 <www.nytimes.com/2001/04/18/arts/japanese-agree-a-stolen-statue-willbe-sent-back-to-china.html>

Stamatoudi, Irini A. , Cultural Property Law and Restitution: A Commentary to International Conventions and European Union law (Edward Elgar Publishing, 2011)

Urbinati, Sabrina , 'Alternative Dispute Resolution Mechanisms in Cultural Property Related Disputes: UNESCO Mediation and Conciliation Procedures.' in Valentina Vadi and Hildegard Schneider (eds), Art, Cultural Heritage and the Market (Springer, 2014) 93

\section{Return of Historically Removed Heritage}

\section{'Ancient Olympia Recommendation', UNESCO, 2013}

$<$ www.unesco.org/fileadmin/MULTIMEDIA/HQ/CLT/pdf/Ancient_Olympia_Recommendation. pdf>

'Conclusions of the Athens International Conference on the Return of Cultural Objects to their Countries of Origin', UNESCO, 2008 <www.unesco.org/culture/laws/pdf/Conclusions>

'Cultural Exchange', Ministry of Foreign Affairs of the People's Republic of China, November 152000

<www.fmprc.gov.cn/mfa_eng/wjb_663304/zzjg_663340/yzs_663350/gjlb_663354/2721_6634 46/2722_663448/t15970.shtml>

'Intergovernmental Committee for Promoting the Return of Cultural Property to its Countries of Origin or its Restitution in Case of Illicit Appropriation, Sixteenth session', UNESCO, September 21-23 2010 <http://unesdoc.unesco.org/images/0019/001925/192583e.pdf> 'Japan-China Relations (Basic Data)', Ministry of Foreign Affairs of Japan, 2012 $<$ www.mofa.go.jp/region/asia-paci/china/data.html>

'Japan-DPRK Pyongyang Declaration', Ministry of Foreign Affairs of Japan, September 17 2002 <www.mofa.go.jp/region/asia-paci/n_korea/pmv0209/pyongyang.html> 
'Japan Returns Historic Victory Monument to Korea', Chosun October 202005

<http://english.chosun.com/site/data/html dir/2005/10/20/2005102061026.html>

'Japanese Funds-in-Trust for the Preservation of the World Cultural Heritage', UNESCO $<$ http://whc.unesco.org/en/partners/277>

'New Scheme to Protect Cultural Sites from Destruction', UK Government, October 282015 $<$ www.gov.uk/government/news/new-scheme-to-protect-cultural-sites-from-destruction> 'Preservation of the Koguryo Kingdom Tombs', UNESCO

$<$ http://whc.unesco.org/en/list/1091>

'Recent Examples of Successful Operations of Cultural Property Restitutions in the World',

UNESCO <www.unesco.org/new/en/culture/themes/restitution-of-cultural-

property/successful-restitutions-in-the-world/>

'Resolution A.67/L.34 of 5 December 2012 about Return and Restitution of Cultural Property', United Nations General Assembly <www.un.org/ga/search/view_doc.asp?symbol=A/67/L.34>

'Resolutions adopted by the United Nations General Assembly about Return and Restitution of Cultural Property', UNESCO <www.unesco.org/new/en/culture/themes/restitution-of-

cultural-property/resolutions-adopted-by-the-united-nations-general-assembly-about-returnand-restitution-of-cultural-property/>

'Treaty of Peace and Friendship between Japan and People's Republic of China', 1978 $<$ www.mofa.go.jp/region/asia-paci/china/treaty78.html>

'Turkey to Receive Hittite Sphinx', Press and Information Office of the Federal Government, May $132011<w w w . b u n d e s r e g i e r u n g . d e / C o n t e n t A r c h i v / E N / A r c h i v 17 /$ Anlagen/2011-05-13pm-sphinx-translation.pdf?_blob=publicationFile\&v=1>

'Uigwe: The Royal Protocols of the Joseon Dynasty', UNESCO

$<$ www.unesco.org/fileadmin/MULTIMEDIA/HQ/Cl/Cl/pdf/mow/nomination_forms/republic_of_ korea_uigwe.pdf>

Art Law Centre, University of Geneva, 'Bogazköy Sphinx-Turkey and Germany', University of Geneva, 2013 <https://plone.unige.ch/art-adr/cases-affaires/bogazkoy-sphinx-2013-turkeyand-germany>

Bassiouni, M. Cherif , 'Reflections on Criminal Jurisdiction in International Protection of Cultural Property' (1983 10(2) Syracuse Journal of International Law and Commerce 281

Beurden, Jos van , 'How to Break the Deadlock in the Debate About Colonial Acquisitions?' in Valentina Vadi and Hildegard Schneider (eds), Art, Cultural Heritage and the Market:

Ethical and Legal Issues (Springer, 2014) 165

Boylan, Patrick J , 'Illicit Trafficking in Antiquities and Museum Ethics' in Kathryn Walker Tubb (ed), Antiquities: Trade or Betrayed: Legal, Ethical, and Conservation Issues (Archetype Publications Ltd, 1995) 94

Carpentier, Laurent , 'French Museums Face a Cultural Change over Restitution of Colonial Objects', Guardian November 32014 <www.theguardian.com/world/2014/nov/03/francemuseums-restitution-colonial-objects>

Chechi, Alessandro, 'Multi-Level Cooperation to Safeguard the Human Dimension of Cultural Heritage and to Secure the Return of Wrongfully Removed Cultural Objects' in Silvia Borelli and Federico Lenzerini (eds), Cultural Heritage, Cultural Rights, Cultural Diversity (Martinus Nijhoff Publishers, 2012) 347

Chechi, Alessandro, The Settlement of International Cultural Heritage Disputes (Oxford University Press, 2014)

Cornu, Marie and Marc-André Renold, 'New Developments in the Restitution of Cultural Property: Alternative Means of Dispute Resolution' (2010 17(1) International Journal of Cultural Property 1

Demetriou, Danielle , 'Japan Returns Looted South Korean Documents to Homeland', Telegraph December 62011

$<$ www.telegraph.co.uk/news/worldnews/asia/japan/8937503/Japan-returns-looted-SouthKorean-documents-to-homeland.html>

Fackler, Martin , 'In Textbook Fight, Japan Leaders Seek to Recast History', New York Times December 282013 <www.nytimes.com/2013/12/29/world/asia/japan-fights-a-political-battleusing-history-texts.html?_r=0>

Fackler, Martin , 'Japan Apologizes to South Korea on Colonization', New York Times August 102010 <www.nytimes.com/2010/08/11/world/asia/11japan.html?_r=1> 
Faure, Guy and Scientific World, New Dynamics Between China and Japan in Asia: How to Build the Future from the Past? (World Scientific Pub. Co, 2010)

Francioni, Francesco and Federico Lenzerini , 'The Destruction of the Buddhas of Bamiyan and International Law' (2003 14(4) European Journal of International Law 619

Gerstenblith, Patty. , 'The Meaning of 1970 for the Acquisition of Archaeological Objects' (2013 38(4) Journal of Field Archaeology 364

Green, Simon Mackenzie and Penny, 'Introduction: A Context for the Engagement of

Criminology and Archaeology' in Simon Mackenzie and Penny Green (eds), Criminology and Archaeology: Studies in Looted Antiquities (Hart Publishing, 2009) 1

Gusten, Susanne, 'Turkey Presses Harder for Return of Antiquities', New York Times May

$252011<$ www.nytimes.com/2011/05/26/world/europe/26iht-M26C-TURKEY-

RETURN.html?pagewanted=all\&_r=0>

Han, Song , 'The 4th International Conference of Experts on the Return of Cultural Property

Opens', China Culture September 122014 <www.chinaculture.org/info/2014-

09/12/content 563202.htm>

He, Xueling , 'Dunhuang Declaration Adopted', China Culture September 162014

$<$ www.chinaculture.org/info/2014-09/16/content_563722.htm>

Jakubowski, Andrzej , State Succession in Cultural Property (Oxford University Press, 2015)

Koo, Melissa (YoungJae) , 'Notes: Repatriation of Korean Cultural Property Looted by Japan-

Can a Sincere Apology Resolve the Centuries-old Korea/Japan Disputes?' (2015 16 Cardozo Journal of Conflict Resolution 625

Lee, Claire , 'The Long Journey: Repatriating "Uigwe"', Korea Herald December 72010 <www.koreaherald.com/view.php?ud=20101207000942>

Palmer, Norman , 'Alternative Procedures, Litigation: The Best Remedy?' in Lyndel Prott (ed), Witnesses to History: A Compendium of Documents 2009 and Writings on the Return of Cultural Objects (United Nations Educational, Scientific and Cultural Organization, 2009) 358

Palmer, Norman , 'Itinerant Art and the Architecture of Immunity from Legal Process:

Questions of Policy and Drafting' (2011 16(1) Art, Antiquity \& Law 1

Prott, Lyndel , 'The Ethics and Law of Returns' (2009 61(1-2) Museum International 101

Reppas, Michael , 'Deflowering of the Parthenon: A Legal and Moral Analysis on Why the

Elgin Marbles Must be Returned to Greece' (1999 9 Fordham Intellectual Property, Media and Entertainment aw Journal 911

Reppas, Michael J., II , 'Empty “International” Museums' Trophy Cases of Their Looted Treasures and Return Stolen Property to the Countries of Origin and the Rightful Heirs of those Wrongfully Dispossessed' (2007 36(1) Denver Journal of International Law and Policy 93

Riding, Alan, 'Return of Booty Protested In France', New York Times September 291993 <www.nytimes.com/1993/09/29/books/return-of-booty-protested-in-france.html>

Scott, Cynthia , 'Sharing the Divisions of the Colonial Past: An Assessment of the Netherlands-Indonesia Shared Cultural Heritage Project, 2003-2006' (2014 20(2) International Journal of Heritage Studies 181

Scott, Geoffrey R. , 'Spoliation, Cultural property, and Japan' (2008 29(4) University of Pennsylvania Journal of International Law 803

Sheng, Gao , "Recovering Illegally Removed Cultural Property and Improving Cultural Property Protection: A Chinese Perspective' (2009 (1) Art Antiquity and Law 1

Stamatoudi, Irini A. , Cultural Property Law and Restitution: A Commentary to International Conventions and European Union law (Edward Elgar Publishing, 2011) 